\title{
24. COCCOLITH AND SILICOFLAGELLATE STRATIGRAPHY, NORTHWESTERN PACIFIC OCEAN, DEEP SEA DRILLING PROJECT LEG 32
}

\author{
David Bukry, United States Geological Survey, La Jolla, California
}

\section{INTRODUCTION}

Leg 32 of the Deep Sea Drilling Project, August to October 1973, which began at Hakodate, Japan, and ended at Honolulu, Hawaii (Figure 1), recovered 249 cores at 11 drilling sites, Sites 303-313. Light-microscope techniques were used for preliminary study of 1000 samples for coccolith and silicoflagellate stratigraphy. This chapter summarizes the stratigraphy at the drill sites (Figures 2 and 3 ) and illustrates parts of the fossil phytoplankton assemblages.

\section{COCCOLITH ZONES}

The Cenozoic zonation (Tables 1 and 2) used for biostratigraphy of DSDP Leg 32 samples is based on Bukry (1973a). Several new subzones have been incorporated and are discussed below from youngest to oldest.

\section{Ceratolithus cristatus Subzone}

Boundary species: Top-Emiliania huxleyi, first occurrence; bottom-Emiliania ovata, last occurrence.

Assemblage: Ceratolithus cristatus, Coccolithus pelagicus, C. pliopelagicus, Crenalithus productellus, Cyclococcolithina leptopora, Discosphaera tubifera, Gephyrocapsa aperta, G. caribbeanica, G. oceanica, G. omega, Hayaster perplexus, Helicopontosphaera kamptneri, $H$. wallichii, Oolithotus antillarum, Pontosphaera scutellum, Rhabdosphaera claviger, Syracosphaera spp., Umbellosphaera irregularis, Umbilicosphaera hulburtiana, U. sibogae.

Remarks: The assemblage listed is a composite of warm- and cool-water species. The significance of late Quaternary assemblages has been discussed by Gartner (1972). The Ceratolithus cristatus Subzone is the same interval as the Gephyrocapsa Zone of Gartner (1969) and

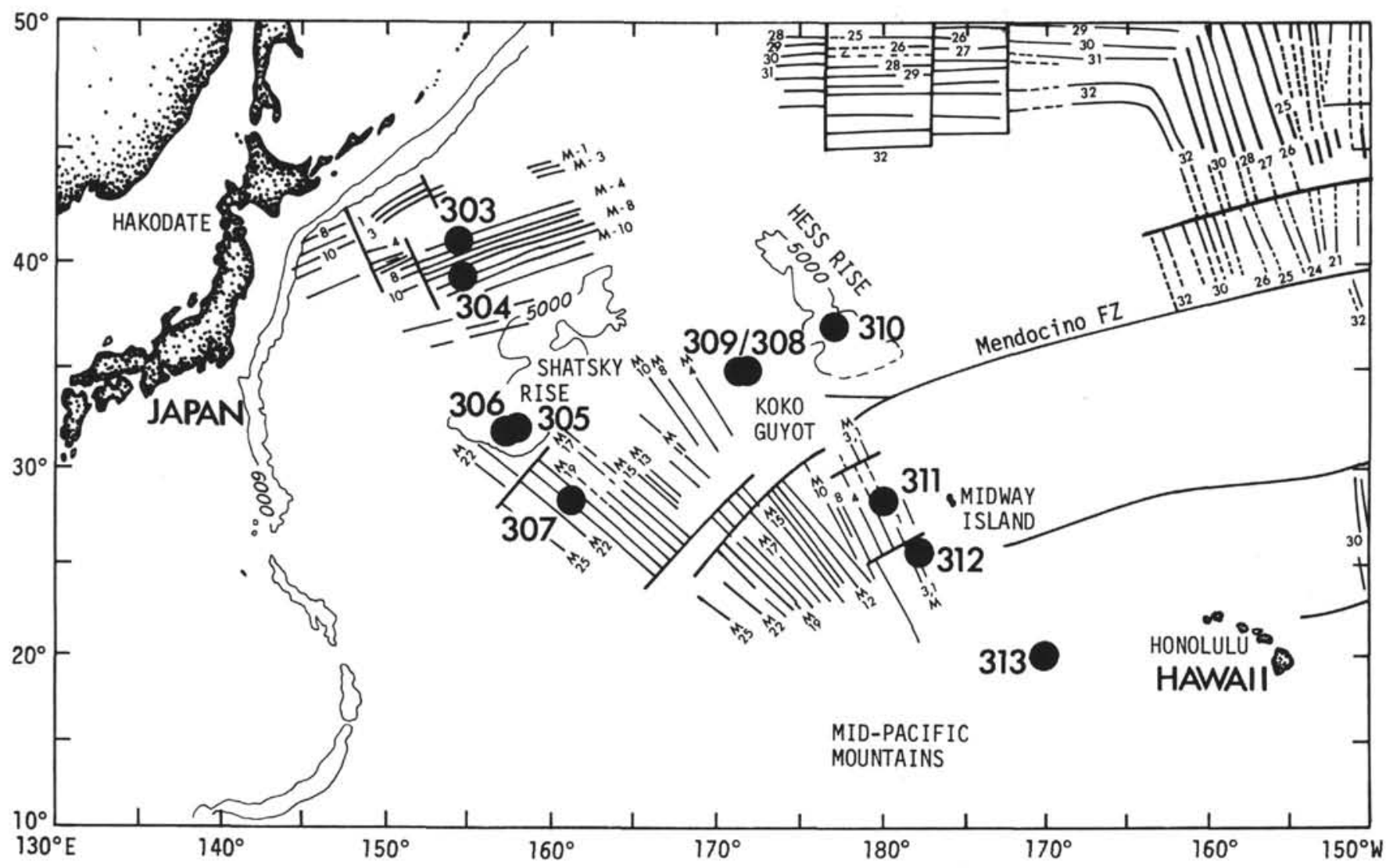

Figure 1. Sketch map showing sites investigated during Deep Sea Drilling Project Leg 32. Numbered lines are magnetic lineations; lines intersecting them are fracture zones. 


\begin{tabular}{|c|c|c|c|c|c|c|c|c|c|}
\hline AGE & ZONE & SUBZONE & \multicolumn{7}{|c|}{ DSDP Site } \\
\hline \multirow{5}{*}{ 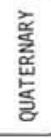 } & \multicolumn{2}{|l|}{ Dniliania huxleyt } & $1-1 / 1-2$ & \multirow{3}{*}{$1-1$} & \multirow{3}{*}{$1-1 / 1-1$} & \multirow{2}{*}{$1, c c$} & \multirow{3}{*}{\begin{tabular}{l|l}
$2-1$ \\
$2-3 / 3-4$
\end{tabular}${ }^{1-1}$} & & \multirow{9}{*}{$1-1 / 1-5$} \\
\hline & \multirow{2}{*}{$\begin{array}{l}\text { Gephyrocapea } \\
\text { oceanica }\end{array}$} & Ceratolithus cristatus & $? 1-3$ & & & & & & \\
\hline & & Eniliania ovata & $1-4 / 1-6$ & & & & & & \\
\hline & \multirow{2}{*}{$\begin{array}{l}\text { Crenatithus } \\
\text { doronicoides }\end{array}$} & Gephyrocapea oaribbeanica & $1, \mathrm{CC} / 2-1$ & & & & \multirow{2}{*}{$\frac{3-5 / ? 3-6}{4-1 / 4-4}$} & & \\
\hline & & Bnitiania annata & $? 2-2$ & & & & & & \\
\hline \multirow{8}{*}{$\begin{array}{l}\text { 㟥 } \\
\text { 岂 }\end{array}$} & \multirow{4}{*}{$\begin{array}{c}\text { Diecoaster } \\
\text { brouweri }\end{array}$} & Cyolococoolithina macintyrei & $2-3 / 2, \mathrm{CC}$ & & & & & & \\
\hline & & Discoaster pentaradiatue & & & & & & & \\
\hline & & Discoaster surculus & $3-1$ & & & & $4-4 / 5-1$ & & \\
\hline & & Discoaster tamalis & $3-2 / 5-1$ & & & & $5-2 / 6-4$ & & \\
\hline & \multirow{2}{*}{$\begin{array}{r}\text { Reticulofenestra } \\
\text { pseudowmbilica }\end{array}$} & Discoaster asymetriaus & & & & & & & \\
\hline & & Sphenotithus neoabies & & & & & & & \\
\hline & Ceratolithus & Ceratolithus mugosus & $5-2$ & & & & $6-5 / 7-2$ & & \\
\hline & & Ceratolithus acutue & $? 5-3 / 5-4$ & & & & $37-3$ & & \\
\hline & & Triquetrorhabdulus megosus & & & & & & & \\
\hline & $\begin{array}{l}\text { Discoaster } \\
\text { quinqueranus }\end{array}$ & Ceratolithus prinus & $5-4 / 6-2$ & & & & $7-4 / 8-4$ & & $1-6 / 1-6$ \\
\hline & & Discoaster berggrenii & $6-3$ & & & & $8-5 / ? 8-6$ & & \\
\hline & $\begin{array}{l}\text { Discoaster } \\
\text { neoharatus }\end{array}$ & $\begin{array}{l}\text { Discoaster neorectus } \\
\text { Discoaster bellus }\end{array}$ & $6-3$ & & & & \begin{tabular}{l|l}
$9-1 / 9-3$ &
\end{tabular} & & \\
\hline & Discoaster & Catinaster calyoutus & & & & & $9-4 / 9-5$ & & \\
\hline 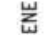 & hamatus & Helicopontosphaera kamptneri & $6-4$ & & & & & & \\
\hline 岩 & Catinaster coalitus & & $6-4$ & & & & $? 9-5$ & & \\
\hline & Discoaster & \begin{tabular}{|l|} 
Discoaster kugleri \\
\end{tabular} & & & & & & & \\
\hline & exilis & Cocootithus miopelagious & & & & & $9-6 / 9-6$ & & \\
\hline & Sphenotithus hetero & & $6-4 / 6-5$ & & & & & & $2-1 / 2, \mathrm{CC}$ \\
\hline & Helicopontoephaera & erta & $6-5$ & & & & & & \\
\hline & Sphenotithus betemn & & & & & & & & \\
\hline & Triquetrorhabdulus & Discoaster druggii & & & & & & & \\
\hline & carinatus & & & & & & & & \\
\hline & Sphenolithus & $\begin{array}{l}\text { Cyclicargolithus abisectus } \\
\text { Dictyococoites bisectus }\end{array}$ & $6-5$ & & & & & & $3-1 / 3-4$ \\
\hline 岸 & ciperoensis & $\begin{array}{l}\text { Dictyococoites bisectus } \\
\text { Cyclicargotithus floridanus }\end{array}$ & $6, \mathrm{CC} / 7-1$ & & & & & & $\frac{3-1 / 3-4}{3-5}$ \\
\hline 岁 & Sphenolithus disten & & $7-2 / 8-3$ & & & & & $3-1$ & $3-6 / 3, \mathrm{CC}$ \\
\hline 号 & Sphenolithus predis & & $8-4 / 8-6$ & & & & & & $4-2 / 4, \mathrm{CC}$ \\
\hline ठ & Helicopontosphaera & Reticulofenestra hillae & & & & & & & \\
\hline & reticulata & Coocolithus formosus & $8, \mathrm{CC} / 9-1$ & & & & $9, \mathrm{CC} / 10-4$ & & $4-1 / 4-1$ \\
\hline & & Coccolithus subdistichus & $9-2 / 9-3$ & & & & $10-5 / 10-6$ & & $5-0$ \\
\hline & $\begin{array}{l}\text { Discoaster } \\
\text { barbadiensis }\end{array}$ & $\begin{array}{l}\text { Is thmolithus recurvus } \\
\text { Chiagnotithes oamaruensis }\end{array}$ & $\frac{9-4 / 9-6}{9, C C}$ & & & & & & $5-0 / 5-1$ \\
\hline & Retioulofenes tra & Discoaster saipanensis & $10-1 / 10, \mathrm{CC}$ & & & & & & $5-2 / 5, \mathrm{CC}$ \\
\hline & unbilica & Discoaster bifax & & & & & & & $6-1 / 7-5$ \\
\hline & & Coocolithus staurion & & & & & & & $7-5 / 7, \mathrm{CC}$ \\
\hline & quadrata & Chiasmolithue gigas & & & & & $10-6$ & & $8, \mathrm{CC}$ \\
\hline 岧 & & Discoaster strictus & & & & & & & \\
\hline & Discoaster & Rhabdosphaera inflata & & & & & & & \\
\hline & sublodoeneis & Discoasteroides kuepperi & $11-1$ & & & & $11-1$ & & \\
\hline & Discoaster Lodoensi & & $11-2 / 11-5$ & & $1-1 / 2, C C$ & & $11-3 / 11, \mathrm{CC}$ & & $9-1 / 9, \mathrm{CC}$ \\
\hline & $\begin{array}{l}\text { Tribrachiatus ortho } \\
\end{array}$ & & $11-6 / 12, \mathrm{CC}$ & & & & & & $12-1 / 13-1$ \\
\hline & Discoaster & Discoaster binodosus & & & & & & & $13-2 / 14, C C$ \\
\hline & diastypus & Tribrachiatus contortus & & & & & & & \\
\hline & Discoaster & Compylosphaera eodela & $13-1 / 13-6$ & & & & & & \\
\hline & multiradiatus & Chiaamolithus bidens & & & & & & & \\
\hline$\overline{\mathrm{J}}$ & Discoaster nobilis & & $13-6 / 13, \mathrm{CC}$ & & & & & & \\
\hline 岁 & $\begin{array}{l}\text { Discoaster mohleri } \\
\text { Heliotithus kleinpe }\end{array}$ & & $14-1 / 14-3$ & & & & & & \\
\hline & $\begin{array}{l}\text { Heliotithus kleimpe } \\
\text { Fasciculithus tympa }\end{array}$ & & $14-3 / 14-4$ & & & & & & \\
\hline & Cruciplacolithus te & & $14-5 / 14, \mathrm{CC}$ & & & & & & \\
\hline
\end{tabular}

Figure 2. Cenozoic coccolith zonation of core samples from Deep Sea Drilling Project Leg 32. The numbers assigned to zonal intervals are core and section numbers of samples examined. A core is typically 9 meters long, a section a sixth part of a core, 1.5 meters, both numbered from the top. CC is a core-catcher sample below Section 6 . Where a zone or subzone is represented in samples from two or more core sections, the highest and lowest are given.

the Gephyrocapsa oceanica Zone of Martini (1971); as such it constitutes only the upper part of the Gephyrocapsa oceanica Zone of Boudreaux and Hay (1967) and Bukry (1973a). The disappearance of Emiliania annula is noted slightly before that of $E$. ovata (Hay, 1970).

\section{Emiliania ovata Subzone}

Boundary species: Top-Emiliania ovata, last occurence; bottom-Gephyrocapsa oceanica, first occurrence.

Assemblage: Ceratolithus cristatus, Coccolithus pelagicus, C. pliopelagicus, Crenalithus doronicoides, C. productellus, Cyclococcolithina leptopora, Discosphaera tubifera, Emiliania annula, E. ovata, Gephyrocapsa aperta, G. caribbeanica, G. oceanica, G. omega, Hayaster perplexus, Helicopontosphaera kamptneri, $H$. sellii, $H$. wallichii, Oolithotus antillarum, Pontosphaera scutellum, Rhabdosphaera claviger, Scyphosphaera pulcherrima, Syracosphaera spp., Umbilicosphaera sibogae.

Remarks: The Emiliania ovata Subzone includes the lower part of the Gephyrocapsa oceanica Zone of Bukry (1973a) and is equivalent to the upper part of the Pseudoemiliania Zone of Gartner (1969) or the Pseudoemiliania lacunosa Zone of Martini (1971).

\section{Discoaster surculus Subzone}

Boundary species: Top-Discoaster surculus, last occurrence; bottom-Discoaster tamalis, last occurrence.

Assemblage: Ceratolithus rugosus, C. telesmus, Coccolithus pelagicus, Crenalithus doronicoides, Cyclococcolithina leptopora, C. macintyrei, Discoaster asymmetricus, D. brouweri, D. intercalaris, D. pentaradiatus, D. 
COCCOLITH AND SILICOFLAGELLATE STRATIGRAPHY

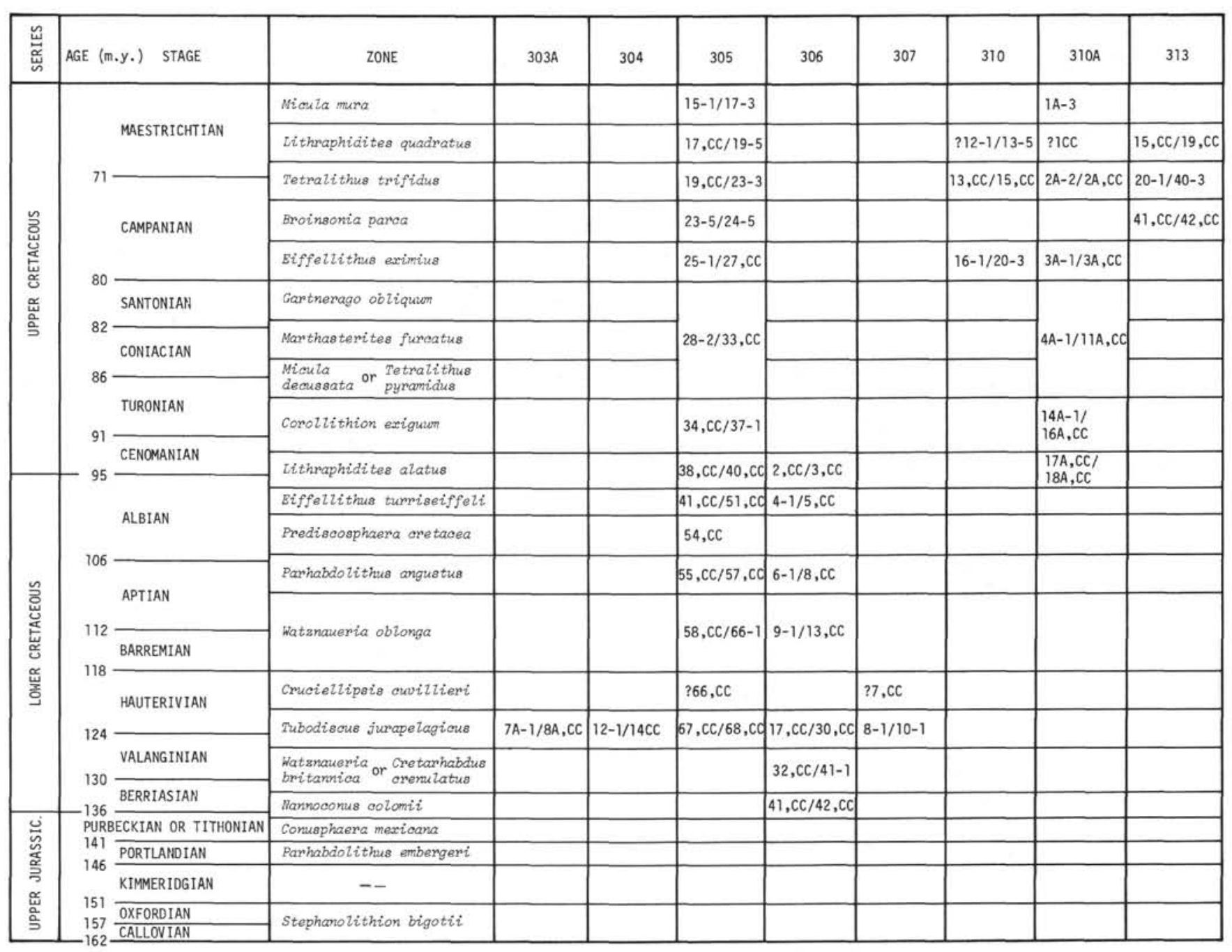

Figure 3. Mesozoic coccolith zonation of core samples from Deep Sea Drilling Project Leg 32 based on Roth (1973) and Thierstein (in press). The numbers assigned to zonal intervals are core and section numbers of samples examined.

surculus, D. triradiatus, Discolithina japonica, Emiliania sp. cf. E. annula, Hayaster perplexus, Helicopontosphaera kamptneri, $H$. sellii, Oolithotus antillarum, Rhabdosphaera claviger, $R$. procera, Scyphosphaera pulcherrima, Syracosphaera spp., Thoracosphaera spp.

Remarks: Sampling interval, sedimentation rate, and degree of reworking may determine whether this brief subzonal interval can be identified (Bukry, 1973a). The sequential extinction of species of Discoaster, following the middle Pliocene acmes of $D$. asymmetricus and $D$. tamalis at low latitude, suggests that in sections where $D$. pentaradiatus and $D$. surculus occur $D$. surculus is the first to disappear. The Discoaster surculus Subzone represents the upper part of the Discoaster surculus Zone of Martini (1971) and Gartner (1969).

Use of the Discoaster surculus Zone requires redefinition of the base of the Discoaster pentaradiatus Subzone of Bukry (1971, 1973a). The last occurrence of Discoaster surculus is the new criteria that makes the amended $D$. pentaradiatus Subzone equivalent to the $D$. pentaradiatus Zone of Martini (1971).

In cooler areas within the range of discoasters, Discoaster surculus and $D$. intercalaris seem to be more common relative to $D$. brouweri and $D$. pentaradiatus (Figure 4). The moderately large-knobbed and broaderrayed species $D$. intercalaris may have been recorded together with $D$. brouweri in some species lists, but it is distinguishable from $D$. brouweri which has only a small central knob and blade-like rays that bend sharply upwards. The relative abundance of these two species appears to coincide with the latitude of compared sites.

\section{Catinaster calyculus Subzone}

Boundary species: Top-Discoaster hamatus, last occurrence; bottom-Catinaster calyculus, first occurrence.

Assemblage: Same as Discoaster hamatus Zone assemblage listed in Bukry (1973a).

Remarks: This subzone for the upper part of the Discoaster hamatus Zone was suggested in Bukry (1973a).

\section{Helicopontosphaera kamptneri Subzone}

Boundary species: Top-Catinaster calyculus, first occurrence; bottom-Discoaster hamatus, first occurrence. 
TABLE 1

Summary of Revised Low-latitude Coccolith Zones and Subzones for the Cenozoic Based on Bukry (1973a)

\begin{tabular}{|c|c|c|c|}
\hline Age & Zone & Subzone & Boundary Species \\
\hline \multirow{4}{*}{ 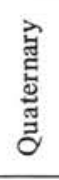 } & \multicolumn{2}{|l|}{ Emiliania huxleyi } & E. huxleyi* \\
\hline & $\begin{array}{l}\text { Gephyrocapsa } \\
\text { oceanica }\end{array}$ & Ceratolithus cristatus & E. ovata $\dagger$, E. annula $\dagger$ \\
\hline & \multirow{2}{*}{$\begin{array}{l}\text { Crenalithus } \\
\text { doronicoides }\end{array}$} & $\begin{array}{l}\text { Emiliania ovata } \\
\text { Gephyrocapsa caribbeanica }\end{array}$ & G. oceanica* \\
\hline & & $\begin{array}{l}\text { Gephyrocapsa caribbeanica } \\
\text { Emiliania annula }\end{array}$ & G. caribbeanica* \\
\hline \multirow{8}{*}{ ֻ } & \multirow{4}{*}{$\begin{array}{r}\text { Discoaster } \\
\text { brouweri }\end{array}$} & Cyclococcolithina macintyrei & D. brouweri† \\
\hline & & Discoaster pentaradiatus & D. pentaradiatus $\dagger$ \\
\hline & & Discoaster surculus & D. surculus $\dagger$ \\
\hline & & Discoaster tamalis & D. tamalis $\dagger$ \\
\hline & \multirow{2}{*}{$\begin{array}{l}\text { Reticulofenestra } \\
\text { pseudoumbilica }\end{array}$} & Discoaster asymmetricus & R. pseudoumbilica $\dagger$, S. neoabies $\dagger$ \\
\hline & & Sphenolithus neoabies & D. asymmetricus A* \\
\hline & \multirow{3}{*}{$\begin{array}{l}\text { Ceratolithus } \\
\text { tricorniculatus }\end{array}$} & Ceratolithus rugosus & C. primus $\dagger$, C. tricorniculatus $\dagger$ \\
\hline & & Ceratolithus acutus & C. rugosus*, C. acutus $\dagger$ \\
\hline \multirow{13}{*}{$\begin{array}{l}\stackrel{\Xi}{\Xi} \\
\stackrel{\Xi}{\Sigma}\end{array}$} & & Triquetrorhabdulus rugosus & C. acutus*, T. rugosusं \\
\hline & \multirow{2}{*}{$\begin{array}{l}\text { Discoaster } \\
\text { quinqueramus }\end{array}$} & Ceratolithus primus & D. quinqueramust \\
\hline & & Discoaster berggrenii & C. primus* \\
\hline & \multirow{2}{*}{$\begin{array}{l}\text { Discoaster } \\
\text { neohamatus }\end{array}$} & Discoaster neorectus & D. berggrenii ${ }^{*}, D$. surculus $*$ \\
\hline & & Discoaster bellus & D. neorectus* ${ }^{*}$ D. loeblichii ${ }^{*}$ \\
\hline & \multirow{2}{*}{$\begin{array}{l}\text { Discoaster } \\
\text { hamatus }\end{array}$} & Catinaster calyculus & D. hamatus $\dagger$ \\
\hline & & Helicopontosphaera kamptneri & $\begin{array}{l}\text { C. calyculus* } \\
\text { D. hamatus* }\end{array}$ \\
\hline & \multicolumn{2}{|l|}{ Catinaster coalitus } & C. coalitus* \\
\hline & $\begin{array}{l}\text { Discoaster } \\
\text { exilis }\end{array}$ & $\begin{array}{l}\text { Discoaster kugleri } \\
\text { Coccolithus miopelagicus }\end{array}$ & D. kugleri*, C. floridanus $\dagger$ \\
\hline & \multicolumn{2}{|c|}{ Sphenolithus heteromorphus } & S. heteromorphus $\dagger$ \\
\hline & \multicolumn{2}{|c|}{ Helicopontosphaera ampliaperta } & C. macintyre ${ }^{*}, D$. deflandrei $\mathrm{A}_{\dagger}^{\dagger}$ \\
\hline & \multicolumn{2}{|c|}{ Sphenolithus belemnos } & S. heteromorphus* \\
\hline & \multirow{3}{*}{$\begin{array}{l}\text { Triquetrorhabdulus } \\
\text { carinatus }\end{array}$} & Discoaster druggii & S. belemnos* \\
\hline \multirow{8}{*}{ 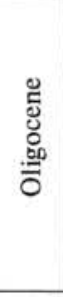 } & & Discoaster deflandrei & D. druggii* \\
\hline & & Cyclicargolithus abisectus & $\begin{array}{l}\text { C. abisectus A } \dagger \\
\text { S. ciperoensis } \dagger, D \text {. bisectus } \dagger\end{array}$ \\
\hline & $\begin{array}{l}\text { Sphenolithus } \\
\text { ciperoensis }\end{array}$ & Dictyococcites bisectus & $\begin{array}{l}\text { S. ciperoensis } \dagger, D \text {. bisectus } \dagger \\
\text { S. distentus } \dagger\end{array}$ \\
\hline & $\begin{array}{l}\text { ciperoensis } \\
\text { Sphenolithus distent }\end{array}$ & Cyclicargolithus floridanus & $\begin{array}{l}\text { S. distentus } \dagger \\
\text { S. ciperoensis* }\end{array}$ \\
\hline & $\begin{array}{l}\text { Sphenolithus distent } \\
\text { Sphenolithus predist }\end{array}$ & & $\begin{array}{l}\text { S. ciperoensts } \\
\text { S. distentus* }\end{array}$ \\
\hline & & $\begin{array}{l}\text { tus } \\
\text { Reticulofenestra hillae }\end{array}$ & R. hillae $\dagger$, R. umbilica $\dagger$ \\
\hline & $\begin{array}{l}\text { Helicopontosphaera } \\
\text { reticulato }\end{array}$ & Coccolithus formosus & C. formosus $\dagger$ \\
\hline & & Coccolithus subdistichus & C. subdistichus $\mathrm{A} \dagger$ \\
\hline & Discoaster & Isthmolithus recurvus & D. barbadiensis $\dagger$, D. saipanensis $\dagger$ \\
\hline & barbadiensis & Chiasmolithus oamaruensis & I. recurvus* \\
\hline & Reticulofenestra & Discoaster saipanensis & C. grandis $\dagger, C$. oamaruensis* \\
\hline & umbilica & Discoaster bifax & C. solitus $\uparrow$, D. bifax $\uparrow$ \\
\hline & & Coccolithus staurion & R. umbilica*, D. bifax* \\
\hline & $\begin{array}{l}\text { auadrata } \\
\text { quatetrina }\end{array}$ & Chiasmolithus gigas & C. gigast \\
\hline 苛 & & Discoaster strictus & C. gigas* \\
\hline & Discoaster & Rhabdosphaera inflata & N. quadrata*, R. inflata $\dot{\dagger}$ \\
\hline & sublodoensis & Discoasteroides kuepperi & R. inflata* \\
\hline & Discoaster lodoensis & & D. sublodoensis* \\
\hline & Tribrachiatus orthos & & C. crassus* \\
\hline & Discoaster & Discoaster binodosus & D. lodoensis* \\
\hline & diastypus & Tribrachiatus contortus & T. contortus $\dagger$ \\
\hline & Discoaster & Campylosphaera eodela & D. diastypus* ${ }^{*}, T$. contortus ${ }^{*}$ \\
\hline & multiradiatus & Chiasmolithus bidens & C. eodela* \\
\hline & Discoaster nobilis & & D. multiradiatus* \\
\hline ठू & Discoaster mohleri & & D. nobilis* \\
\hline नัँ & Heliolithus kleinpelli & & D. mohleri* \\
\hline & Fasciculithus tympar & ormis & H. kleinpellii* \\
\hline & Cruciplacolithus ten & & F. tympaniformis* \\
\hline
\end{tabular}

Note: ${ }^{*}=$ appearance, $\dagger=$ disappearance, $\mathrm{A}^{*}=$ beginning of acme, $\mathrm{A} \dagger=$ end of acme. 
TABLE 2

Coccolith Zones and Subzones with Estimated Time Relations (Ages Modified from Berggren and Van Couvering [1973], Bukry [1973b], Gartner

[1972, 1973], and Theyer and Hammond [1974])

\begin{tabular}{|c|c|c|c|c|}
\hline Age & Zone & Subzone & $\begin{array}{l}\text { Duration } \\
\text { (m.y.) }\end{array}$ & $\begin{array}{c}\text { Boundary } \\
\text { (m.y.) }\end{array}$ \\
\hline \multirow{5}{*}{ 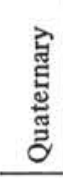 } & \multicolumn{2}{|l|}{ Emiliania huxleyi } & 0.2 & 0.2 \\
\hline & \multirow{2}{*}{$\begin{array}{l}\text { Gephyrocapsa } \\
\text { oceanica }\end{array}$} & Ceratolithus cristatus & 0.1 & 0.3 \\
\hline & & Emiliania ovata & 0.6 & 0.9 \\
\hline & \multirow{2}{*}{$\begin{array}{l}\text { Crenalithus } \\
\text { doronicoides }\end{array}$} & Gephyrocapsa caribbeanica & 0.7 & 1.6 \\
\hline & & Emiliania annula & 0.2 & 1.8 \\
\hline \multirow{8}{*}{ 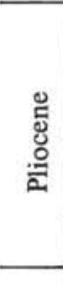 } & \multirow{4}{*}{$\begin{array}{r}\text { Discoaster } \\
\text { brouweri }\end{array}$} & Cyclococcolithina macintyrei & 0.2 & 2.0 \\
\hline & & Discoaster pentaradiatus & 0.1 & 2.1 \\
\hline & & Discoaster surculus & 0.4 & 2.5 \\
\hline & & Discoaster tamalis & 0.5 & 3.0 \\
\hline & \multirow{2}{*}{$\begin{array}{l}\text { Reticulofenestra } \\
\text { pseudoumbilica }\end{array}$} & Discoaster asymmetricus & 0.5 & 3.5 \\
\hline & & Sphenolithus neoabies & 0.5 & 4.0 \\
\hline & \multirow{2}{*}{$\begin{array}{l}\text { Ceratolithus } \\
\text { tricorniculatus }\end{array}$} & Ceratolithus rugosus & 0.4 & 4.4 \\
\hline & & Ceratolithus acutus & 0.6 & 5.0 \\
\hline \multirow{14}{*}{ 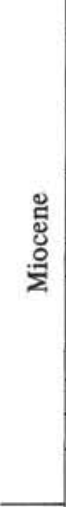 } & \multirow{2}{*}{$\begin{array}{l}\text { Discoaster } \\
\text { quinqueramus }\end{array}$} & Triquetrorhabdulus rugosus & 0.6 & 5.6 \\
\hline & & \begin{tabular}{|l} 
Ceratolithus primus \\
Discoaster berggrenii
\end{tabular} & $\frac{1.0}{0.4}$ & 6.6 \\
\hline & \multirow{2}{*}{$\begin{array}{l}\text { Discoaster } \\
\text { neohamatus }\end{array}$} & & $\begin{array}{l}0.4 \\
0.5\end{array}$ & 7.0 \\
\hline & & \begin{tabular}{|l} 
Discoaster neorectus \\
Discoaster bellus
\end{tabular} & $\frac{0.5}{3.5}$ & 7.5 \\
\hline & \multirow{2}{*}{$\begin{array}{l}\text { Discoaster } \\
\text { hamatus }\end{array}$} & \begin{tabular}{|l|} 
Discoaster bellus \\
Catinaster calyculus \\
\end{tabular} & $\begin{array}{l}3.5 \\
1.0\end{array}$ & 11.0 \\
\hline & & $\begin{array}{l}\text { Catinaster calyculus } \\
\text { Helicopontosphaera kamptneri }\end{array}$ & 1.0 & 12.0 \\
\hline & \multicolumn{2}{|l|}{ Catinaster coalitus } & 0.2 & 13.0 \\
\hline & \multirow{2}{*}{$\begin{array}{l}\text { Discoaster } \\
\text { exilis }\end{array}$} & Discoaster kugleri & 0.2 & 13.2 \\
\hline & & Coccolithus miopelagicus & 0.6 & 13.4 \\
\hline & \multicolumn{2}{|c|}{ Sphenolithus heteromorphus } & 1.0 & 14.0 \\
\hline & \multicolumn{2}{|c|}{ Helicopontosphaera ampliaperta } & 2.0 & 15.0 \\
\hline & \multicolumn{2}{|c|}{ Sphenolithus belemnos } & 1.0 & 17.0 \\
\hline & & Discoaster druggii & 3.0 & 18.0 \\
\hline & Trinatus & Discoaster deflandrei & 2.0 & 21.0 \\
\hline \multirow{8}{*}{ 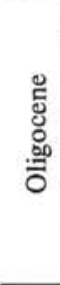 } & & Cyclicargolithus abisectus & 1.0 & 23.0 \\
\hline & Sphenolithus & Dictyococcites bisectus & 1.0 & 24.0 \\
\hline & ciperoensis & Cyclicargolithus floridanus & 1.5 & 25.0 \\
\hline & Sphenolithus distent & & 3.5 & 26.5 \\
\hline & Sphenolithus predist & & 4.0 & 30.0 \\
\hline & & Reticulofenestra hillae & 0.5 & 34.0 \\
\hline & Helicopontosphaera & Coccolithus formosus & 2.5 & 34.5 \\
\hline & & Coccolithus subdistichus & 1.0 & $\frac{37.0}{380}$ \\
\hline & Discoaster & Isthmolithus recurvus & 3.0 & 38.0 \\
\hline & barbadiensis & Chiasmolithus oamaruensis & 1.0 & 41.0 \\
\hline & Reticulofenestra & Discoaster saipanensis & 2.0 & 42.0 \\
\hline & umbilica & Discoaster bifax & 1.0 & 44.0 \\
\hline & & Coccolithus staurion & 1.5 & 45.0 \\
\hline & Nannotetrina & Chiasmolithus gigas & 0.5 & 46.5 \\
\hline ¿ & & Discoaster strictus & 1.0 & 47.0 \\
\hline 体 & Discoaster & Rhabdosphaera inflata & 1.0 & 48.0 \\
\hline & sublodoensis & Discoasteroides kuepperi & 0.5 & 49.0 \\
\hline & Discoaster lodoensis & & 0.5 & 49.5 \\
\hline & Tribrachiatus orthos & & 2.0 & 50.0 \\
\hline & Discoaster & Discoaster binodosus & 0.8 & 52.0 \\
\hline & diastypus & Tribrachiatus contortus & 0.7 & 52.8 \\
\hline & Discoaster & Campylosphaera eodela & 0.5 & 53.5 \\
\hline & multiradiatus & Chiasmolithus bidens & 1.0 & 54.0 \\
\hline & Discoaster nobilis & & 0.5 & 55.0 \\
\hline ల్ & Discoaster mohleri & & 1.5 & 55.5 \\
\hline 巳 & Heliolithus kleinpelli & & 1.0 & 57.0 \\
\hline 2 & Fasciculithus tympar & ormis & 2.0 & 58.0 \\
\hline & Cruciplacolithus tent & & 30 & 60.0 \\
\hline & & & & 63.0 \\
\hline
\end{tabular}




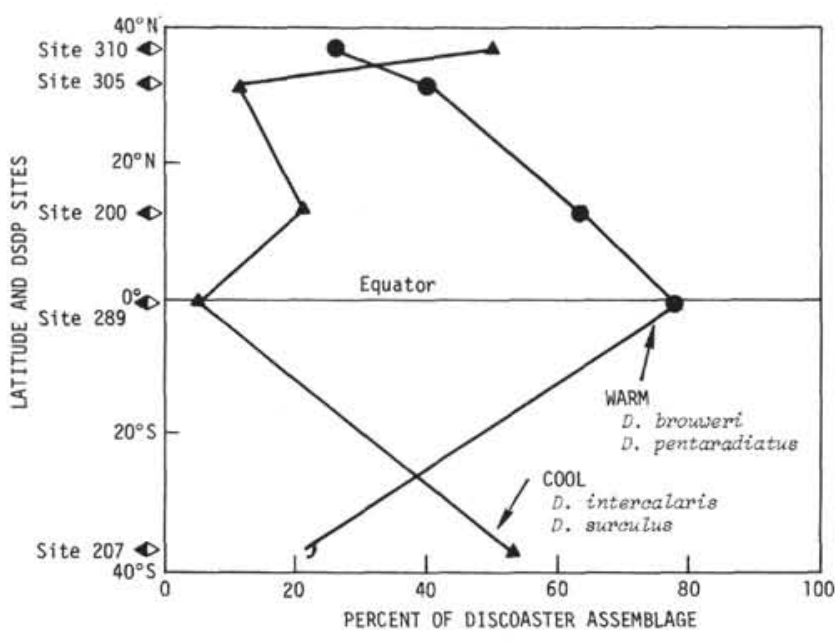

Figure 4. Relative abundance of temperature-indicating Discoaster species in the late Pliocene Discoaster tamalis Subzone from a north-south transect of Deep Sea Drilling Project sites in the Western Pacific. Discoaster brouweri and D. pentaradiatus are most common in warm areas and D. intercalaris and D. surculus in cool areas.

Assemblage: With the exception of the absence of Catinaster calyculus, the assemblage is the same as that of the Catinaster calyculus Subzone.

Remarks: This subzone for the lower part of the Discoaster hamatus Zone was proposed in Bukry (1973a). Five-rayed discoasters are usually less abundant in the lower part of $D$. hamatus Zone than in the upper.

\section{Dictyococcites bisectus Subzone}

Boundary species: Top-Sphenolithus ciperoensis and Dictyococcites bisectus, last occurrence; bottom-Sphenolithus distentus, last occurrence.

Assemblage: Chiasmolithus altus, Coccolithus eopelagicus, $C$. sp. aff. $C$. fenestratus, $C$. miopelagicus (rare), C. pelagicus, Cyclicargolithus abisectus, C. floridanus, Dictyococcites bisectus, D. scrippsae, Discoaster deflandrei, Discolithina segmenta, Helicopontosphaera intermedia (rare), $H$, recta (rare), Reticulofenestra gartneri, Sphenolithus ciperoensis, $S$. dissimilis, $S$. moriformis, Triquetrorhabdulus carinatus.

Remarks: The Dictyococcites bisectus Subzone is equivalent to the upper part of the Sphenolithus ciperoensis Zone of Bukry and Bramlette (1970), and Bukry (1971, 1973a). Although Martini (1971), Perch-Nielsen (1972), Burns et al. (1973), and Hay and Beaudry (1973) use the last Helicopontosphaera recta, a sporadic fossil in oceanic assemblages, to mark the top of their $S$. ciperoensis Zones, they all employ the last Sphenolithus distentus for the base. This provides a mutual point of correlation for the new Dictyococcites bisectus Subzone.

\section{Cyclicargolithus floridanus Subzone}

Boundary species: Top-Sphenolithus distentus, last occurrence; bottom-Sphenolithus ciperoensis, first occurrence.

Assemblage: Same as that of the Dictyococcites bisectus Subzone except for the additional presence of Sphenolithus distentus.
Remarks: The Cyclicargolithus floridanus Subzone constitutes the lower part of the Sphenolithus ciperoensis Zone of Bukry and Bramlette (1970), and Bukry (1971, 1973a). It corresponds to the Sphenolithus distentus Zone of Martini (1971), Perch-Nielsen (1972), and Hay and Beaudry (1973).

\section{Isthmolithus recurvus Subzone}

Boundary species: Top-Discoaster barbadiensis and D. saipanensis, last occurrence; bottom-Isthmolithus recurvus, first occurrence.

Assemblage: Bramletteius serraculoides, Chiasmolithus altus, $C$. oamaruensis, Coccolithus eopelagicus, $C$. formosus, C. pelagicus, C. subdistichus s. ampl., Cyclicargolithus floridanus, Dictyococcites bisectus, $D$. scrippsae, Discoaster barbadiensis, D. deflandrei, $D$. nodifer, D. saipanensis, D. tanii, Helicopontosphaera compacta, Isthmolithus recurvus, Pontosphaera vadosa, Reticulofenestra hillae, $R$. reticulata, $R$. samodurovi, $R$. umbilica, Sphenolithus moriformis, $S$. predistentus, $S$. pseudoradians.

Remarks: The Isthmolithus recurvus Subzone constitutes the upper part of the Discoaster barbadiensis Zone of Bukry and Bramlette (1970), Bukry (1971, 1973a), Roth and Thierstein (1972), Roth (1973), and Gartner (1974). It corresponds to the interval of the Sphenolithus pseudoradians Zone and Isthmolithus recurvus Zone of Martini (1971). The distribution of Isthmolithus recurvus in Deep Sea Drilling Project cores containing sediment of its maximum age range of late Eocene to early Oligocene shows that it can be considered a consistent marker fossil only at latitudes higher than $30^{\circ}$ north or south. It is typically absent at tropical sites (Figure 5) and is best considered a restricted subzonal marker. Of 43 DSDP sites between latitudes $30^{\circ} \mathrm{S}$ and $30^{\circ} \mathrm{N}, I$. recurvus occurs in only 7 and this area, where the tropical coccolith zonation is most effectively employed, constitutes $50 \%$ of the earth's surface area.

\section{Chiasmolithus oamaruensis Subzone}

Boundary species: Top-Isthmolithus recurvus, first occurrence; bottom-Chiasmolithus grandis, last occurrence.

Assemblage: Same as the Isthmolithus recurvus Subzone, with the exception that Isthmolithus recurvus is missing.

Remarks: The Chiasmolithus oamaruensis Subzone may be recognized as the lower part of the Discoaster barbadiensis Zone in assemblages where the presence of Isthmolithus recurvus can be established. It corresponds to the Chiasmolithus oamaruensis Zone of Martini (1971) and Edwards (1971). Chiasmolithus oamaruensis is most typical in middle to high latitude assemblages and its first occurrence approximates the last occurrence of $C$. grandis.

\section{Discoaster binodosus Subzone}

Boundary species: Top-Discoaster lodoensis, first occurrence; bottom-Tribrachiatus contortus, last occurrence.

Assemblage: Campylosphaera dela, C. eodela, Chiasmolithus sp. cf. C. bidens, $C$. consuetus, Coccolithus 


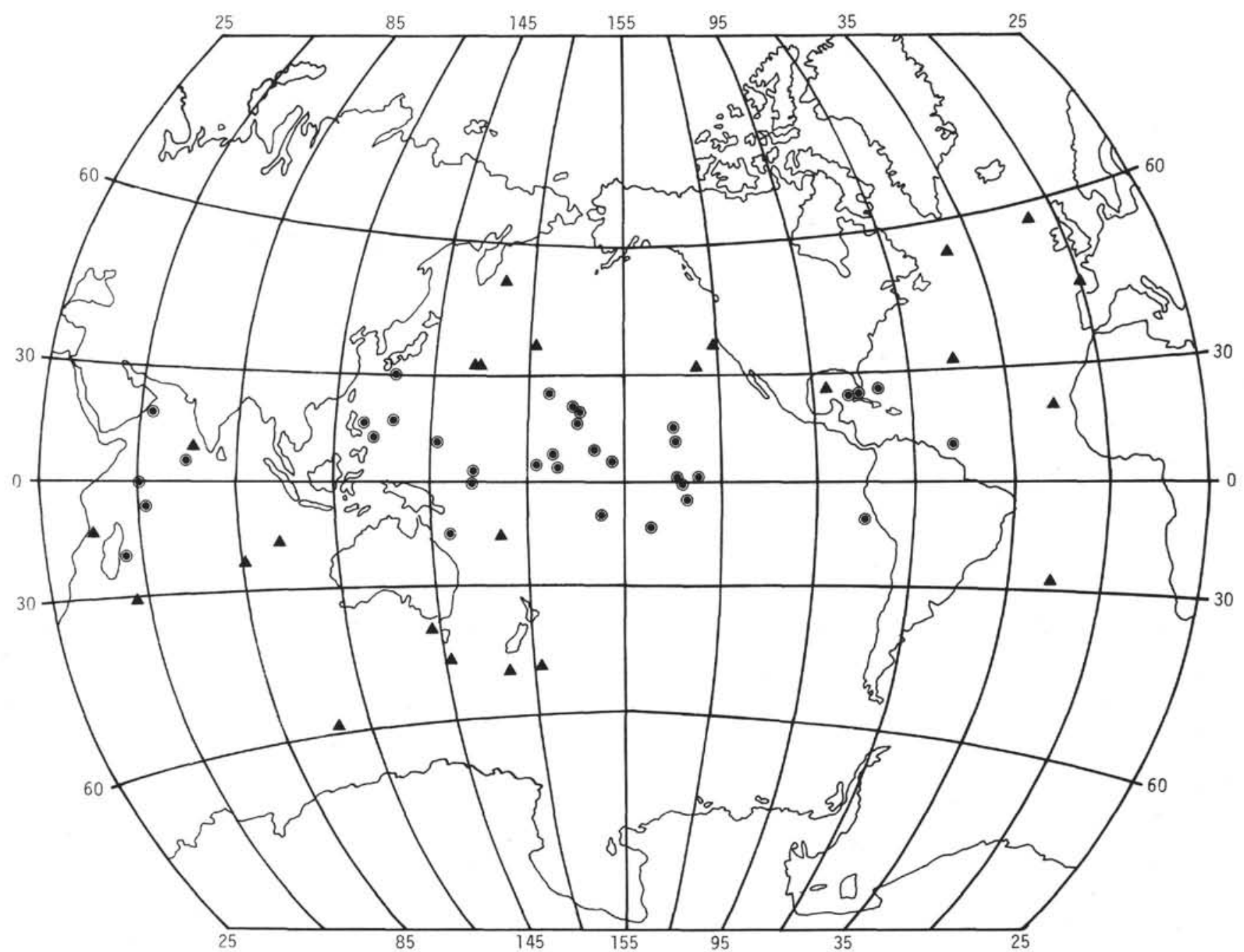

Figure 5. Distribution of Isthmolithus recurvus at DSDP sites where late Eocene or early Oligocene sediment was recovered.

$\boldsymbol{\Delta}=$ present,$\quad 0=$ absent .

pelagicus, Discoaster barbadiensis, D. binodosus, D. diastypus, D. lenticularis, D. nobilis, Ellipsolithus macellus, Lophodolithus nascens, Sphenolithus radians, Tribrachiatus orthostylus, Zygrhablithus bijugatus, $Z$. dispar.

Remarks: The Discoaster binodosus Subzone constitutes the upper part of the Discoaster diastypus Zone of Bukry and Bramlette (1970), Bukry (1971, 1973a), and Roth (1973). It is identical to the Discoaster binodosus Zone of Mohler and Hay (1967), Martini (1971), and Burns et al. (1973). Because identification of Tribrachiatus contortus is commonly difficult in pelagic sediments, which show secondary overgrowths, this stratigraphic unit is employed as a subzone.

\section{Tribrachiatus contortus Subzone}

Boundary species: Top-Tribrachiatus contortus, last occurrence; bottom-Discoaster diastypus, first occurrence.

Assemblage: Campylosphaera dela, C. eodela, Chiasmolithus sp. cf. C. bidens, C. consuetus, C. pelagicus, Discoaster binodosus, D. diastypus, D. lenticularis, D. multiradiatus, D. nobilis, Ellipsolithus distichus, E. macellus, Lophodolithus nascens, Sphenolithus radians, Toweius craticulus, Tribrachiatus contortus, T. orthostylus, Zygrhablithus bijugatus, $Z$. dispar.

Remarks: The Tribrachiatus contortus Subzone constitutes the lower part of the Discoaster diastypus Zone of Bukry (1973a). It is similar to the Marthasterites contortus Zone of Mohler and Hay (1967) and Martini (1971) because it shares the same upper boundary criterion, but the basal criterion differs from their use of first Marthasterites bramlettei (=Tribrachiatus nunnii [Gartner] n. comb.; basionym: Marthasterites nunnii nom. nov., substitute name for Marthasterites bramlettei Brönnimann and Stradner, 1960, Erdoel-Z., v. 76, p. 366, fig. 17-20, 23, 24; proposed by Gartner, 1971, Tulane Stud. Geol. Paleontol., v. 8, p. 116).

\section{SITE SUMMARIES}

Site 303

(lat $40^{\circ} 48.50^{\prime} \mathrm{N}$, long $154^{\circ} 27.07^{\prime} \mathrm{E}$, depth $5609 \mathrm{~m}$ )

Site 303, east of Hakodate, Japan, at Mesozoic magnetic anomaly M-4 on the Japanese magnetic lineation pattern, was drilled to obtain a biostratigraphic age 
TABLE 3

Occurrence of Silicoflagellates at Site 303 Recorded as Percent of Total Specimens

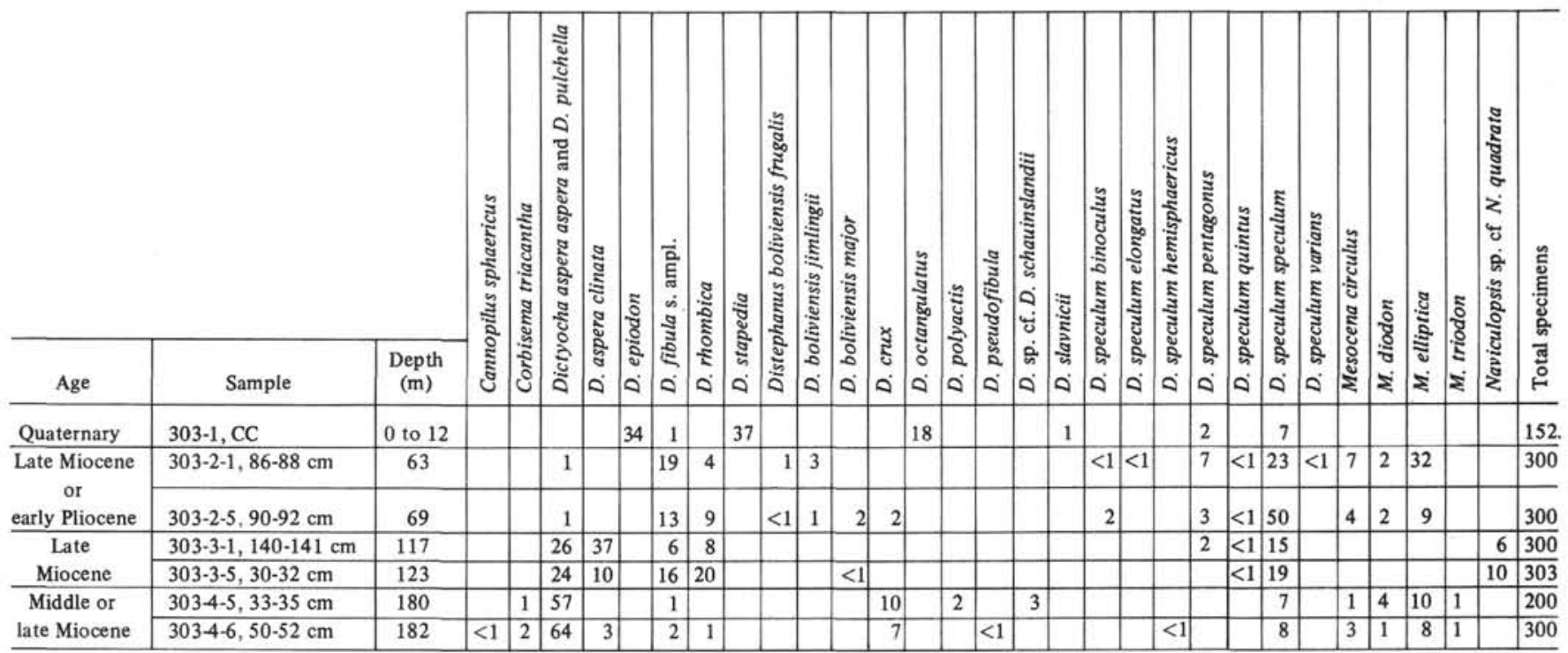

for sediments directly above basement to help calibrate the patterns of Mesozoic magnetic anomalies with the more widely known geologic time scale. To this end, only a few cores were taken at shallow depths.

Cores 1 to 4 , cut discontinuously between 0 to 182 meters, contain Neogene sediment rich in siliceous phytoplankton but lack calcareous microfossils because of complete carbonate dissolution at the great depth of this site. Diatom stratigraphy is discussed by Koizumi (this volume). The silicoflagellate stratigraphy, shown in Table 3 shows that the near-surface silicoflagellate assemblages reflect a transitional climatic regime having representatives of cool-water (Distephanus octangulatus) and warm-water (Dictyocha fibula) species, in addition to broadly tolerant taxa such as Dictyocha epiodon.

Cores 5 and $1 \mathrm{~A}$ to $6 \mathrm{~A}$ (211 to $266 \mathrm{~m}$ ) are barren of phytoplankton.

Coccoliths are present in only the lowest two cores of sediment, Cores 7A and 8A (266 to $285 \mathrm{~m}$ ), above basalt, Cores 9A and 10A (285 to $293 \mathrm{~m}$ ). Although the Early Cretaceous coccolith assemblages are common to abundant, preservation is poor and many stratigraphically diagnostic species are missing. Identification of rare Tubodiscus sp. cf. T. verenae indicates a probable Valanginian or Hauterivian age (124 \pm 9 m.y.).

\section{Site 304}

(lat $39^{\circ} 20.27^{\prime} \mathrm{N}$, long $155^{\circ} 04.19^{\prime} \mathrm{E}$, depth $5630 \mathrm{~m}$ )

Site 304 is just southeast of Site 303 at Mesozoic magnetic anomaly M-9 in the Japanese magnetic lineation pattern. This site was drilled to obtain a biostratigraphic age from sediment directly above basement so that the relative ages at Sites 303 and 304 could be used to help calibrate the Mesozoic magnetic anomaly pattern. Although basal sediment and basalt was obtained at both sites, the state of fossil preservation is quite different and the age difference between the sites is within the present range of resolution of a single biostratigraphic zone.
Coccoliths occur in the lowest four cores above basalt (Cores 12 to $15 ; 318$ to $335 \mathrm{~m}$ ). In Core 15 , coccoliths were recovered only from thin coatings (originally laminae?) on chert fragments. These assemblages have limited diversity and suggest an Early Cretaceous age. The best assemblages, from the carmine and orange clays of Cores 13 and 14 , contain more definitive assemblages that indicate Valanginian to Hauterivian age (124 \pm 9 m.y.). Stratigraphic guide species present include: Cruciellipsis cuvillieri, Diadorhombus rectus, and Tubodiscus verenae. Tubodiscus verenae is distinguished from Tubodiscus jurapelagicus by its larger central opening, narrower rim, and less robust tube cycle.

The basal clays of Cores 13 and 14 are lithologically correlative to Core $8 \mathrm{~A}$ at Site 303, although preservation of coccoliths is distinctly better and diversity is greater in the two Site 304 cores. Distinguishing the younger Site 303 on magnetic anomaly M-4 from the older Site 304 on magnetic anomaly M-9 is difficult, not only because of differences in preservation, but because the broad stratigraphic resolution of planktonic microfossils in the Early Cretaceous (zones of 3 to 7 m.y. duration) approaches the extrapolated age difference of 5 m.y. between these two magnetic anomalies.

Late Miocene or early Pliocene diatoms and silicoflagellates are common to abundant and well preserved throughout Core 1 (106 to $115 \mathrm{~m}$ ). Mesocena circulus constitutes up to $17 \%$ of the silicoflagellate population, suggesting proximity to the Miocene-Pliocene boundary (Stadum and Burckle, 1973; Bukry, in press a). Dictyocha predominates over Distephanus indicating warmwater conditions. Assemblages of Cores 1 and 2 are charted in Table 4. Deeper samples are barren of siliceous phytoplankters.

\section{Site 305}

(lat $32^{\circ} 00.13^{\prime} \mathrm{N}$, long $157^{\circ} 51.00^{\prime} \mathrm{E}$, depth $2903 \mathrm{~m}$ )

At Site 305, on the crest of Shatsky Rise, the goal was to obtain a biostratigraphic reference section. Our suc- 
TABLE 4

Occurrence of Silicoflagellates in Cores 1 and 2 at Site 304 Recorded as Percent of Total Specimens

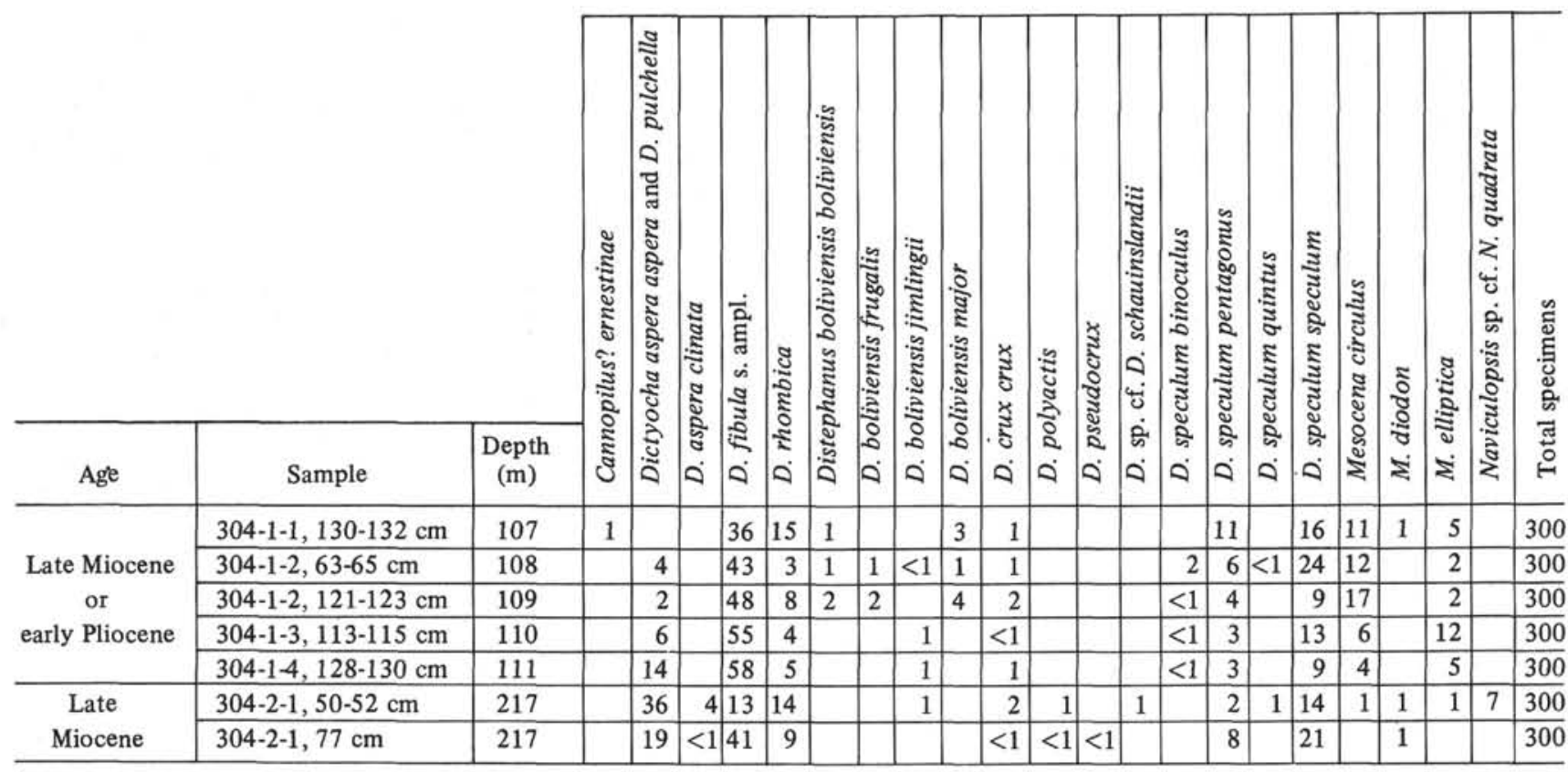

cess was limited by stratigraphic unconformities, poor fossil preservation, drilling disturbance of sediment, and a $33 \%$ core recovery.

Coccoliths are generally abundant throughout the 641-meter continuously cored section (Cores 1 to 68). Preservation is moderate to poor, as overgrowths and fragmentation have affected most assemblages. Most of the Miocene is missing in the Cenozoic section of Cores 1 to $14(0$ to $130 \mathrm{~m})$. The Mesozoic appears to be complete from Maestrichtian to Valanginian or Hauterivian in Cores 15 to 68 (130 to $641 \mathrm{~m}$ ); recovery of only trace amounts of sediment below Campanian Core 28 reduces the potential value of Site 305 as a reference section.

The Cretaceous-Tertiary boundary is indicated between Cores 14 and 15 at 130 meters. Preservation immediately above and below this level is especially poor. The only definite early Paleocene was recovered as a trace of white clay in the Core 14 core-catcher sample. Micula mura occurs as part of a late Maestrichtian assemblage at the top of Core 15.

Of the three oldest cores at Site 305, Core 67 (626 to $636 \mathrm{~m}$ ) contains the best assemblage. The presence of Cruciellipsis cuvillieri in Cores 66 to 68 establishes the Neocomian age of the basal cores. Species present in Core 67 include: Cretarhabdus crenulatus, Cruciellipsis chiasta, C. cuvillieri, Cyclagelosphaera margerelii, Diadorhombus rectus, Diazomatolithus lehmannii, Lithraphidites carniolensis, Parhabdolithus embergeri, Tubodiscus verenae, Vagalapilla stradneri, Watznaueria barnesae, $W$. bayackii, and $W$. ovata.

\section{Site 306}

\section{(lat $31^{\circ} 52.02^{\prime} \mathrm{N}$, long $157^{\circ} 28.71^{\prime} \mathrm{E}$, depth $3399 \mathrm{~m}$ )}

Site 306 is downslope from Site 305 about $35 \mathrm{~km}$ away on the southwest flank of Shatsky Rise. This location was selected to help achieve penetration of a thick Early
Cretaceous section encountered but incompletely drilled at Site 305.

Coccolith assemblages ranging in age from earliest Cretaceous to Quaternary (Gephyrocapsa oceanica Zone) occur in the 475-meter section (Cores 1 to 42) at Site 306.

Most of the cored section is Early Cretaceous in age and appears to represent continuous deposition. Chert layers are numerous and sediment recovery was negligible.

Core 1 (1 to $10 \mathrm{~m})$ contains a relatively uncontaminated foraminifer-coccolith ooze of Quaternary age at the top; the rest of the core contains a mixture of species representative of most Late Cretaceous and Cenozoic zones. Fragments of chalk in the lower part of the core contain poorly preserved Albian to Turonian coccoliths.

The Lithraphidites alatus Zone, in Cores 2 to 3 (10 to $28 \mathrm{~m}$ ), and the Eiffellithus turriseiffeli Zone, in Cores 4 to 5 (38 to $66 \mathrm{~m}$ ), are both associated with Albian foraminifer assemblages (Cores 2 to 4).

Cores 6 to 8 ( 76 to $123 \mathrm{~m}$ ) contain poorly preserved assemblages of the Aptian to Albian Parhabdolithus angustus Zone. The latest appearance of Watznaueria oblonga here duplicates its occurrence at Site 305 and indicates a correlation for Cores 306-6 and 305-57. Cores 6 to 8 at Site 306 correspond to Cores 55 to 57 at Site 305 . Watznaueria oblonga is a consistent, meager to common member of assemblages between the extinction of Cruciellipsis cuvillieri and the appearance of Parhabdolithus angustus at Sites 305 and 306. Because no Tetralithus malticus is present, the Tetralithus malticus Zone (Roth, 1973 ) is renamed in this report; the original boundary criteria are retained, and the typical assemblage is expanded to include $W$. oblonga. Watznaueria oblonga Bukry (1969) is the senior synonym of Flabellites biforaminis Thierstein (1973). 
The oldest coccolith assemblages at Site 306 in Cores 41 and 42 ( 373 to $392 \mathrm{~m}$ ) are below the local ranges of such marker species as Cruciellipsis cuvillieri and Nannoconus colomii. A compared identification of rare specimens of Cretarhabdus sp. cf. C. angustiforatus and Cruciellipsis sp. cf. C. cuvillieri, however, suggests an earliest Berriasian assignment (Thierstein, in press).

\section{Site 307}

\section{(lat $28^{\circ} 35.26^{\prime} \mathrm{N}$, long $161^{\circ} 00.28^{\prime} \mathrm{E}$, depth $5696 \mathrm{~m}$ )}

Site 307, southeast of Shatsky Rise at Mesozoic magnetic anomaly M-21 in the Hawaiian magnetic lineation pattern, was drilled to obtain a biostratigraphic age for sediment directly above basement.

Samples from Cores 1 to 6 ( 0 to $131 \mathrm{~m})$ are barren or contain only trace numbers of Watznaueria barnesae, the predominant Mesozoic species of coccoliths. A poor Early Cretaceous assemblage from Core 7 (158 to 167 $\mathrm{m}$ ) is composed of resistant long-ranged species.

Cores 8 to 10 (195 to $279 \mathrm{~m})$ contain Cruciellipsis cuvillieri, indicating a Neocomian age. The Valanginian to Hauterivian portion of the Neocomian is suggested by the presence of species of Tubodiscus in Cores 8 and 10.

Core 11 ( 289 to $298 \mathrm{~m}$ ) is radiolarian-bearing chert. Core 12 (298 to $307 \mathrm{~m}$ ), which recovered red shale and basalt altered to claystone, had only rare long-ranged coccolith species such as Cyclagelosphaera margerelii, Diazomatolithus lehmannii, Watznaueria barnesae, and Watznaueria britannica. This assemblage suggests an indeterminate Late Jurassic to Early Cretaceous range.

\section{Site 308}

\section{(lat $34^{\circ} 58.94^{\prime} \mathrm{N}$, long $172^{\circ} 08.98^{\prime} \mathrm{E}$, depth $1331 \mathrm{~m}$ )}

Site 308, on Koko Seamount near the southern end of the Emperor Seamount chain, was intended to provide biostratigraphic confirmation of the radiometric age of the guyot and to obtain an extensive record of the underlying basalt for paleomagnetic dating and comparative petrology. Only a few sediment cores were obtained.

Sparse late Quaternary assemblages are present in the upper half meter of Core 1. Early Eocene Discoaster lodoensis Zone shallow-water assemblages are present in Cores 1 to $2(0.5$ to $22 \mathrm{~m})$. Cores 3 and $4(41$ to $69 \mathrm{~m})$ contain only rare undiagnostic placoliths. The common occurrence of genera Braarudosphaera, Micrantholithus, and Rhabdosphaera indicates shallow-water deposition. The stratigraphic coincidence of Discoaster lodoensis and Lophodolithus nascens in the absence of Tribrachiatus orthostylus and Discoaster sublodoensis is used to zone the assemblages of Cores 1 to 2. The Discoaster lodoensis Zone nominally represents the period 50 to $51 \mathrm{~m} . \mathrm{y}$. On this basis, the age and age-error estimate for Cores 1 to 2 is $50.5 \pm 3.5$ m.y.

\section{Site 309}

\section{(lat $34^{\circ} 54.32^{\prime} \mathrm{N}$, long $171^{\circ} 33.67^{\prime} \mathrm{E}$, depth $1454 \mathrm{~m}$ )}

At Site 309 , on the southwest flank of Koko Seamount, a second unsuccessful attempt to core basement was made; only a single sediment core was retrieved. A Quaternary Gephyrocapsa oceanica Zone assemblage is present in Core 1 core-catcher sample ( 0 to $2 \mathrm{~m}$ ). Ceratolithus cristatus and several forms of Gephyrocapsa are present, suggesting deposition from relatively warm water. Very rare Discoaster specimens are the only indicators of possible reworking.

A Quaternary Pseudoeunotia doliolus Zone diatom assemblage is present in Core 1 core-catcher sample ( 0 to $2 \mathrm{~m}$ ). The rare, poorly preserved specimens of Pseudoeunotia doliolus, Hemidiscus cuneiformis, and Coscinodiscus lineatus suggest deposition from relatively warm water.

\section{Site 310}

(lat $36^{\circ} 52.11^{\prime} \mathrm{N}$, long $176^{\circ} 54.09^{\prime} \mathrm{E}$, depth $3516 \mathrm{~m}$ )

At Site 310 , on the crest of Hess Rise, a continuous coring program was terminated by storm conditions before basement was reached.

Quaternary to Miocene coccoliths in Cores 1 to 8 ( 0 to $72 \mathrm{~m})$ are abundant, and preservation is moderate. Discoasters are common to abundant in Pliocene and Miocene Cores 4 to 8 ( 24 to $72 \mathrm{~m}$ ), but sphenoliths are missing. The assemblages are restricted by the rarity or absence of Discolithina, Rhabdosphaera, and Scyphosphaera. Warm-water species of Discoaster, such as the five-rayed $D$. bellus to $D$. quinqueramus plexus, are rare.

An unconformity in Core 9 (72 to $81 \mathrm{~m})$ juxtaposes middle Miocene assemblages above those of early Oligocene age. The core-catcher sample of Core 11 contains a strongly dissolved assemblage of the Discoaster lodoensis Zone, whereas the top of Core $12(100 \mathrm{~m})$ contains a Late Cretaceous assemblage. No contact was recovered.

Although Cenozoic assemblages could be routinely zoned, marker species are sparse in the Mesozoic section of Cores 12 to 21 (100 to $194 \mathrm{~m}$ ) and Cores 1A to 18A (95 to $353 \mathrm{~m}$ ). The Campanian to Maestrichtian Tetralithus trifidus Zone occurs in Cores 13 to 15 and 2A. The Campanian Eiffellithus eximius Zone occurs in Cores 16 to 20. Coccoliths are generally abundant in the Mesozoic samples recovered but preservation is poor to moderate. Below the Campanian, coccolith samples were often obtained only by scraping sediment encrusted on large pieces of chert. Diagenetically resistant, long-ranged species dominate such material.

Basal age of the Mesozoic section in Core 18A (344 to $353 \mathrm{~m}$ ), based on a moderately well-preserved coccolith assemblage that includes the name-giving species, is late Albian to early Cenomanian Lithraphidites alatus Zone.

\section{Site 311}

\section{(lat $28^{\circ} 07.46^{\prime} \mathrm{N}$, long $179^{\circ} 44.25^{\prime} \mathrm{E}$, depth $5775 \mathrm{~m}$ )}

Coccolith assemblages are present in Cores 2 to 4 ( 9 to $28 \mathrm{~m}$ ) from Site 311 , on the archipelagic apron of the Hawaiian Seamount chain west of Midway Island. In most samples, Cyclicargolithus floridanus constitutes the assemblage, suggesting only a post-Eocene age because of the turbidite origin of the sediment. A sample from Core 3, Section 1, contains Dictyococcites bisectus and Sphenolithus distentus in addition to Cyclicargolithus floridanus. This assemblage indicates the early late Oligocene Sphenolithus distentus Zone (approximately 27 to 30 m.y.). 
Site 312

(lat $25^{\circ} 34.70^{\prime} \mathrm{N}$, long $178^{\circ} 08.00^{\prime} \mathrm{W}$, depth $5345 \mathrm{~m}$ )

No coring was attempted at this location.

\section{Site 313}

(lat $20^{\circ} 10.52^{\prime} \mathrm{N}$, long $170^{\circ} 57.15^{\prime} \mathrm{W}$, depth $3484 \mathrm{~m}$ )

At Site 313 , in an intermontane basin in the northeastern Mid-Pacific Mountains west of Hawaii, coccolith assemblages ranging from Quaternary in Core 1 core catcher $(8 \mathrm{~m})$ to early Eocene Discoaster diastypus Zone in Core 14 core catcher $(233 \mathrm{~m})$ occur in the Cenozoic section. Coccoliths are abundant throughout, but preservation is moderate to poor. Warm-water zonal assemblages with abundant discoasters are present throughout. Reworked specimens are common in Cores 1,5 , and 8 . Cores 5 to 14 ( 159 to $233 \mathrm{~m}$ ) contain a nearly complete array of Eocene zones. The next deeper sample at the top of Core 15 is Late Cretaceous.

Coccoliths are generally abundant and have moderate to poor preservation in the Campanian to Maestrichtian section (Cores 15 to $42 ; 233$ to $588 \mathrm{~m}$ ) recovered above basalt (Cores 43 to $44 ; 588$ to $606 \mathrm{~m}$ ). Most of the Mesozoic section, Cores 20 to 40 , is assigned to the late Campanian to early Maestrichtian Tetralithus trifidus Zone. Coccolith assemblages of Cores 41 and 42 (569 to $588 \mathrm{~m}$ ) are assigned to the subjacent Campanian Broinsonia parca Zone based on the presence of Broinsonia parca and the absence of Eiffellithus eximius and Tetralithus trifidus. The nominal age of the oldest sediment above basalt is therefore late Campanian (76 \pm 5 m.y.).

\section{NEW PHYTOPLANKTON SPECIES FROM LEG 32}

\section{Silicoflagellates}

\section{Genus DICTYOCHA Ehrenberg, 1837 \\ Dictyocha aspera clinata $n$. subsp. \\ (Plate 1, Figures 1-5)}

Dictyocha sp. Ling, 1972 (in part), Am. Paleontol. Bull., v. 62, no. 273, p. 163, pl. 26, fig. 7 .

Dictyocha aspera (Lemmermann) Bukry and Foster, 1973 (in part), Deep Sea Drilling Proj. Initial Rept., v. 16, p. 826, pl. 2, fig. 5. Dictyocha sp. cf. D. aspera (Lemmermann), Bukry, 1973, Deep Sea Drilling Proj. Initial Rept., v. 19, p. 864, pl. 1, fig. 4.

Description: This large-sized silicoflagellate has a rhomboid to rounded rhomboid body ring with radial spines at the four corners. The apical structure is characterized by a relatively long apical bar and four apical struts that elevate the bar above the plane of the body ring. The apical bar is not in line with the short axis of the body ring but inclined at a small angle. The pair of radial spines aligned with the long axis of the body ring are longer than those aligned with the short axis. There is no apical spine on the apical bar.

Remarks: Dictyocha aspera clinata is distinguished from other members of the Dictyocha aspera group of subspecies by the inclined orientation of the apical bar relative to the short axis of the basal ring. The radial spines aligned with long axis are proportionally longer than those of associated D. aspera aspera (Lemmermann) (Bukry, 1975).

Occurrence: Dictyocha aspera clinata occurs in late Miocene sediment from DSDP Sites 303, 304, 192, 158, and the Experimental Mohole cores.

Size: $60-100 \mu$, maximum diameter; holotype $73 \mu$.

Holotype: USNM 210878 (Plate 1, Figure 2).

Paratypes: USNM 210879-210882.
Type locality: Northwest Pacific Ocean, Sample 303-3-5, 30-32 cm $(123 \mathrm{~m})$.

\section{Dictyocha pulchella n.sp.}

(Plate 4, Figures 1-3)

?Dictyocha fibula Ehrenberg, 1854 (in part), Mikrogeologie, pl. 21, fig. $42 \mathrm{~b}$, (not pl. 22, fig. 42ab).

?Dictyocha fibula brevispina Lemmermann, 1901 (in part), fide Loeblich and others, 1966, Geol. Soc. Am. Mem. 106, p. 91, pl. 10, fig. 3 .

Dictyocha fibula Ehrenberg, Bachmann and Ichikawa, 1962 (in part), Kanazawa Univ. Sci. Rept., v. 8, p. 169, pl. 2, fig. 30, pl. 7, fig. 1014.

Dictyocha fibula fibula rhombica Schulz, Glezer, 1966 (in part), Cryptogamic plants USSR, v. 7, p. 267, pl. 15, fig. 4, ?7.

Dictyocha sp. Ling, 1972 (in part), Am. Paleontol. Bull., v. 62, p. 163, pl. 26, fig. 4-6.

Dictyocha cf. aspera Lemmermann, Dumitrica, 1973 (in part), Deep Sea Drilling Proj. Initial Rept., v. 13, p. 907, pl. 7, fig. 4, 6, 7.

Dictyocha lingi Dumitrica, Dumitrica, 1973 (in part), ibid., v. 21, p. 848, pl. 3, fig. 4.

Dictyocha fibula ssp. aspera Lemmermann, Dumitrica, 1973 (in part), ibid., v. 21 , p. 848 , pl. 2 , fig. 4-7, 11, ?12-13.

Dictyocha aspera (Lemmermann), Bukry, 1973, ibid., v. 18, p. 826, pl. 1, fig. 3.

Dictyocha aspera (Lemmermann), Bukry, 1975, ibid., v. 30, pl. I, fig. 9, 10.

Description: Dictyocha pulchella has a basal ring that is generally in the form of a rounded, elongate rhomb. The ratio of the long to short axis is 1-2 (1.1-1.6; 1.3 mean). The four apices are broadly rounded. An apical bar is symmetrically aligned perpendicular to the long axis of the body ring. Apical struts that support the apical bar rise from the upper, inner surface of the basal ring and, with the apical bar, form four openings or portals. The ratio of basal ring length to the length of the two smaller portals is $2-3(2.1-2.8 ; 2.4$ mean). In adapical view, four small accessory spines occur on the inner margin of the body ring at or near the apical struts. These accessory spines give the basal ring a more scalloped appearance in adapical view (compare Plate 4, Figure 1 to Figure 3).

Remarks: Dictyocha pulchella is distinguished from the similar species $D$. aspera aspera by its more rounded apices and typically smaller more elongate basal ring. $D$. pulchella is distinguished from the most similar species, $D$. rhombica (Schulz) (synonyms: $D$. fibula brevispina Lemmermann, D. mutabilis Deflandre, and D. ausonia Deflandre), by its shorter apical bar and by the greater relative length of the two small portals with respect to the long axis of the basal ring. The ratio of the basal-ring length to the small portal length for $D$, pulchella is characteristically $2-3$ (2.4 mean), whereas the ratio for $D$. rhombica is significantly larger $3-5(3.4-4.6 ; 4.0$ mean).

Dictyocha pulchella is distinguished from $D$. fibula-like taxa by the perpendicular orientation of the apical bar to the long axis of the basal ring. However, the similarity in basal ring style and proportions between D. fibula-like and D. aspera-like forms (Bukry, in press, pl. 1) suggests a close affinity between the two types. Subtle convergence and divergence in form from one taxonomic category to another is typical of silicoflagellate assemblages. Therefore, the large populations and wide distribution of $D$. pulchella are helpful in establishing its significance.

Occurrence: Dictyocha pulchella is most common in middle Miocene and early late Miocene silicoflagellate assemblages from the Pacific Ocean. D. pulchella is the dominant form of the $D$. aspera group in the middle or late Miocene sediment of Core 4, Site 303, east of Japan. It is also predominant in middle Miocene (Discoaster hamatus Zone) and late Miocene (Discoaster neohamatus Zone) Cores 3-5 at Site 285, in the South Pacific between Fiji and New Zealand. It is common in sediment as old as the early middle Miocene (Corbisema triacantha Zone) in the Experimental Mohole cores, from offshore Baja California, and in cores from the Southern California Borderland. Specimens cited in the synonymy are from the Mediterranean region and the Pacific.

Size: $25-50 \mu$, basal ring.

Holotype: USNM 213297 (Plate 4, Figure 1).

Paratypes: USNM 213298-213299. $\mathrm{m})$. 
Genus DISTEPHANUS Stöhr, 1880

Distephanus boliviensis boliviensis (Frenguelli)

Dictyocha boliviensis Frenguelli 1940 (in part), p. 44, fig. 4, fide Loeblich and others, 1968, Geol. Soc. Am. Mem. 106, p. 83, pl. 9, fig. 3 .

Dictyocha glabra Frenguelli, 1941, p. 95, pl. 1, fig. 7-9, fide Loeblich and others, 1968, Geol. Soc. Am. Mem. 106, p. 99, pl. 17, fig. 1-3.

Distephanus boliviensis (Frenguelli) Bukry and Foster, 1973, Deep Sea Drilling Proj. Initial Rept., v. 16, p. 827, pl. 4, fig. 1-3.

Remarks: The normal, noncannopilean form of Frenguelli is considered the central species concept. Cannopilean forms of this large species are classified as Distephanus boliviensis major (Frenguelli). Both are distinguished from Distephanus boliviensis frugalis and $D$. boliviensis jimlingii by the larger size of their apical structures. Specimens of the Distephanus boliviensis group of subspecies are distinguished from the Distephanus speculum group of subspecies primarily by their much larger size and more equant radial spines. The separation of normal and cannopilean subspecies in both groups may have some use for paleoecologic statistical reconstructions, and therefore the taxonomic divisions are maintained. But double skeleton sets of a single cell having one normal and one cannopilean skeleton are known for the $D$. speculum group (Gemeinhardt, 1930) and for the D. boliviensis group (Bukry and Foster, 1973).

Several species or varieties of the Distephanus speculum group, such as Distephanus speculum regularis constricta Schulz, and D. rotundus Stöhr, resemble $D$. boliviensis boliviensis but are distinctly smaller. The size and shape of $D$. boliviensis boliviensis (Frenguelli) most accurately matches the populations studied from DSDP sites in the Pacific.

Distephanus boliviensis frugalis n. subsp.

(Plate 2, Figures 2-7)

Distephanus speculum (Ehrenberg) Small apical ring, Bukry, 1973, Deep Sea Drilling Proj. Initial Rept., v. 18, p. 828, pl. 2, fig. 11; pl. 3 , fig. 1 .

Description: Distephanus boliviensis frugalis has a moderately large, nearly equilateral, hexagonal basal ring. The sides are slightly indented at the points of juncture with the apical struts. The radial spines are moderately long and essentially equant. A small apical ring and long apical struts form the apical structure. The distinctive appearance of the skeleton results from the small diameter of the apical ring, typically less than a third the short diameters of the basal ring.

Remarks: Distephanus boliviensis frugalis is distinguished from $D$. boliviensis boliviensis by its smaller apical ring, from $D$. speculum brevispinus by its larger size and longer radial spines, and from Dictyocha gracilis by its larger size and more equant radial spines.

Occurrence: Distephanus boliviensis frugalis is known from the North Pacific in late Miocene and early Pliocene sediment at DSDP Sites 173, 303, and 304. It has not been noted in samples from tropical sites of DSDP Legs 16, 20, or 22.

Size: $60-80 \mu$, maximum diameter; holotype $64 \mu$.

Holotype: USNM 210886 (Plate 2, Figure 6).

Paratypes: USNM 210887-210889.

Type locality: Northwest Pacific Ocean, Sample 304-1-2, 63-65 cm $(108 \mathrm{~m})$.

Distephanus boliviensis jimlingii $\mathbf{n}$. subsp.

(Plate 1, Figures 6, 7; Plate 2, Figure 1)

Cannopilus hemisphaericus (Ehrenberg), Ling, 1973 (in part), Deep Sea Drilling Proj. Initial Rept., v. 19, p. 751, pl. 1, fig. 1, 2.

Cannopilus major (Frenguelli), Bukry, 1973, ibid., v. 19, p. 864, pl. 1, fig. 1-3.

Description: Distephanus boliviensis jimlingii is characterized by an equilateral hexagonal frame with equant radial spines. The apical structure is small with respect to the basal ring and is subdivided into small, rounded, polygonal openings.

Remarks: Distephanus boliviensis jimlingii is distinguished from $D$. boliviensis major by the smaller size of the apical structure. The average values of the ratio of all inner short diameters of the hexagonal basal ring to the coincident maximum apical ring diameters for specimens of D. boliviensis jimlingii, figured here and in Ling (1973) and Bukry (1973b), range from 1.8 to 2.0. Values of the same ratio for specimens of D. boliviensis major, illustrated in Loeblich et al. (1968) and Bukry and Foster (1973), range from 1.3 to 1.6. This morphologic distinction is reflected in the disjunct geographic ranges of the two subspecies; $D$. boliviensis jimlingii is known only from northern areas of the Pacific, whereas $D$. boliviensis major is known to have a wider range, from the North Pacific (Site 303 , lat $41^{\circ} \mathrm{N}$ ), Panama Basin (Site 157 , lat $2^{\circ} \mathrm{S}$ ), and South of Tasmania (Site 278 , lat $57^{\circ} \mathrm{S}$ ). D. boliviensis jimlingii is distinguished from D. speculum hemisphaericus (Ehrenberg) (Bukry, 1975) by smaller apical structure, larger overall size, and equilateral basal ring.

Occurrence: Distephanus boliviensis jimlingii is present in late Miocene or early Pliocene sediment from the North Pacific at DSDP Sites $183,192,303$, and 304 , all north of latitude $39^{\circ} \mathrm{N}$.

Size: $60-80 \mu$, maximum diameter; holotype $66 \mu$.

Holotype: USNM 210883 (Plate 1, Figure 6).

Paratypes: USNM 210884, 210885.

Type locality: Northwest Pacific Ocean, Sample 303-2-5, 90-92 cm $(69 \mathrm{~m})$.

\section{Distephanus boliviensis major (Frenguelli) n. comb.}

Dictyocha boliviensis Frenguelli, 1940 (in part), p. 44, fig. 4 b-d, fide Loeblich et al., 1968, Geol. Soc. Am. Mem. 106, p. 83, pl. 9, fig. 46.

Dictyocha boliviensis major Frenguelli 1951, p. 277, fig. 3 a-c, fide Loeblich et al., 1968, Geol. Soc. Am. Mem. 106, p. 84, pl. 51, fig. 46.

Cannopilus major (Frenguelli) Bukry and Foster, 1973, Deep Sea Drilling Proj. Initial Rept., v. 16, p. 826, pl. 1, fig. 4-7; pl. 7, fig. 4.

Remarks: Specimens of Distephanus boliviensis major from the Panama Basin are distinguished from those of $D$. boliviensis jimlingii from the North Pacific by their distinctly larger apical structures and subdivisions.

Distephanus speculum elongatus n. subsp.

(Plate 2, Figures 8, 9; Plate 3, Figures 1-3)

Distephanus speculum (Ehrenberg), Dumitrica, 1973 (in part), Deep Sea Drilling Proj. Initial Rept., v. 13, p. 908, pl. 10, fig. 6, 7.

Distephanus speculum speculum (Ehrenberg), Bukry, 1974 (in part), ibid., v. 29, pl. 4, fig. 12.

Description: Distephanus speculum elongatus is a small- to moderate-sized subspecies characterized by a large elongate apical ring. Many specimens have small spines on the apical ring that are aligned with the long pair of radial spines. The basal ring is typically a regular hexagon or is only slightly elongate, providing geometric contrast to the more elongate apical ring.

Remarks: Distephanus speculum elongatus most closely resembles D. speculum speculum in size and form. It is distinguished by a pronounced elongation of the apical ring. Although both forms may have small, accessory spines on the apical ring, when present they are larger on $D$. speculum elongatus.

Occurrence: Distephanus speculum elongatus occurs as a minor component of relatively high-latitude Neogene assemblages at DSDP Sites 303,278 , and 124. It is most common at Site 278, where it constitutes $26 \%$ of the Distephanus speculum specimens in Sample 278-8-2, $75 \mathrm{~cm}$.

Size: $30-50 \mu$, maximum diameter; holotype $44 \mu$.

Holotype: USNM 210890 (Plate 2, Figures 8, 9).

Paratypes: USNM 210891, 210892.

Type locality: Northwest Pacific Ocean, Sample 303-2-1, 86-88 cm $(63 \mathrm{~m})$.

Coccoliths

\section{Genus CRENALITHUS Roth, 1973}

Crenalithus productellus n. sp.

Ellipsoplacolithus productus Kamptner, 1963. Ann. Naturh. Mus. Wien, v. 66, p. 172 , pl. 8, fig. 42,44 (invalid).

Ellipsoplacolithus productus Kamptner, Nishida, 1971. Bull. Nara Univ. Educ., v. 20 , p. 89 , pl. 1, fig. 10.

Gephyrocapsa producta (Kamptner), Bukry, 1971, Deep Sea Drilling Proj. Initial Rept., v. 6, p. 990, pl. 2, fig. 2.

?Coccolithus productus, Gartner, 1973, Geol. Soc. Am., v. 84, p. 2029, fig. 5 .

Description: Crenalithus productellus is a small, elliptical placolith having 28-38 subradial rim elements. There is little imbrication of rim elements. The central area is virtually closed along a median slit. The periphery of distal and proximal rims is serrate. In cross-polarized light the central area and rim area is bright and has sharp continuous extinction lines. 
Remarks: Crenalithus productellus is distinguished from $C$. doronicoides by its virtually closed central area. It is distinguished from Gephyrocapsa caribbeanica by lacking any crossbar.

Occurrence: Crenalithus productellus is an abundant member of Quaternary assemblages from middle latitude localities such as Shatsky Rise and Hess Rise in the North Pacific.

Size: $3-8 \mu$.

Holotype: Plate 2, figure 2 of Bukry (1971).

Type locality: Shatsky Rise, DSDP 47.0-1-4, $77-78 \mathrm{~cm}(5 \mathrm{~m})$.

\section{Genus CRASPEDOLITHUS Kamptner, 1963}

Craspedolithus vidalii $\mathbf{n}$. sp.

Cyclolithella annulus (Cohen) McIntyre and Bé, 1967 (in part), DeepSea Res., v. 14, p. 568 , pl. 5, fig. A-B.

Craspedolithus declivus Kamptner, Nishida, 1970, Paleontol. Soc. Japan Trans. Proc., no. 79 , p. 360 , pl. 40 , fig. 6,7

Latin diagnosis: Cricolithus collare angusto, tubo centrale aperto et scuto ampliori compositus. Elementa radialiter orientata plerumque sine imbricatione insigni.

Description: Cricolith composed of a narrow collar, an open central tube, and wide shield. Elements radially oriented, mostly without noticeable imbrication.

As discussed in McIntyre and Bé (1967), this small, circular species is characterized by single shield construction and a central opening bordered by a sloping collar cycle. Rim elements are broad, irregularly shaped and are unimbricate but flush to each other. Rim counts of 16 to 30 are recorded. The central opening varies from less than a third to more than a half of the rim diameter.

Remarks: This unusual species is considered very fragile by McIntyre and Bé (1967). Craspedolithus vidalii is distinguished from Umbilicosphaera hulburtiana Gaarder by its smaller central opening, elongate irregular rim elements, and single shield instead of double rim construction. Craspedolithus vidalii is distinguished from Emiliania annula by solid, single-rim construction and smaller central opening. Craspedolithus declivus can be distinguished from $C$. vidalii by its higher rim counts of $36-48$ and by its very narrow shield cycle.

Occurrence: Craspedolithus vidalii is reported from a water sample taken by the H.M.S. Vidal in 1965 at $21^{\circ} 40^{\prime} \mathrm{N}$ and $31^{\circ} 45^{\prime} \mathrm{W}$ in the Atlantic Ocean (McIntyre and Bé, 1967).

Size: $4-5 \mu$.

Holotype: Plate 5, fig. B of McIntyre and Bé (1967).

Paratype: Plate 5, fig. A of McIntyre and Bé (1967).

Type locality: Atlantic Ocean, $21^{\circ} 40^{\prime} \mathrm{N}, 31^{\circ} 45^{\prime} \mathrm{W}$

\section{Genus CYLINDRALITHUS Bramlette and Martini, 1964 \\ Cylindralithus? echinus n. sp. \\ (Plate 3, Figures 4-11)}

Description: Cylindralithus? echinus skeletons are composed of a short, hollow, cylindrical basal cycle of crystallites and an apical spray of rodlike crystallites arrayed in a nearly hemispherical pattern. The equatorial line at the base of the apical structure contains 13 to 16 radial crystallites, but a polar line contains only about 8 , which reflects a regular arrangement. Whereas the height of the apical spray is greater than the height of the cylindrical base by about $50 \%$, the overall width and height of a skeleton are equivalent. Although the apical spray has no opening, the basal cylinder has a small central opening of variable diameter, generally equal to one half or less the outer diameter of the cylinder. In cross-polarized light, in top or side view, $C$.? echinus remains uniformly bright at all compass orientations. In top view, slightly curved, faint extinction lines appear.

Remarks: Cylindralithus? echinus appears to lack the thin perforated plate or bars at the base characteristic of most species of Cylindralithus. It is distinguished from Cylindralithus nudus, which also lacks a plate or bars, by its distinctive array of apical spines.

Occurrence: Cylindralithus? echinus occurs in a small interval of the lower Maestrichtian at Shatsky Rise and Hess Rise in the northwestern Pacific Ocean. Because of its short range and few to common abundance in cores from Site 305-18 (158 to $167 \mathrm{~m}$ ) and Site $310 \mathrm{~A}-1$ ( 95 to $105 \mathrm{~m})$, it is a potential regional marker species.

Size: $5-10 \mu$, maximum height or width; holotype $7 \mu$.

Holotype: USNM 210893 (Plate 3, Figures 4, 5).

Paratypes: USNM 210894, 210895.

Type locality: Northwest Pacific Ocean, Sample 305-18-3, 120-121 $\mathrm{cm}(161 \mathrm{~m})$.
Genus EMILIANIA Hay and Mohler, 1967

Remarks: The original definition includes all coccoliths with at least one slotted rim of I-shaped elements. Two invalid genera, Ellipsoplacolithus Kamptner, 1963, and Pseudoemiliania Gartner, 1969, share this morphologic character. Ellipsoplacolithus was judged invalid because it violated ICBN (International Code of Botanical Nomenclature) Article 34 prohibiting provisional taxonomy (Loeblich and Tappan, 1966). Among several new taxa described in Kamptner (1963), Ellipsoplacolithus and its new species were set apart by the additional designation of paragenus and paraspecies, implying an uncertain, provisional designation. Because the genus and its type species $E$. lacunosa are invalid, the formation of a new genus Pseudoemiliania with the same type species is also invalid by ICBN Art. 43 (Loeblich and Tappan, 1970).

The currently valid designations of the fossil forms described by Kamptner and Gartner are Emiliania annula (Cohen) and Emiliania ovata Bukry.

\section{Emiliania annula (Cohen) Bukry}

Coccolithites annulus Cohen, 1964. Micropaleontology, v. 10, p. 237, pl. 3, fig. 1a-e.

Coccolithus doronicoides Black and Barnes, McIntyre, Bé, and Preikstas, 1967 (in part), Prog. Oceanogr., v. 4, p. 8, pl. 3, fig. A. Cyclolithella annula (Cohen), Cohen and Reinhardt, 1968. N. Jb. Geol. Pälaont. Abh., v. 131, p. 299, pl. 19, fig. 2 and 6.

Umbilicosphaera cricota (Gartner) Cohen and Reinhardt, 1968. N. Jb. Geol. Pälaont. Abh., v. 131, p. 296, pl. 19, fig. 1 and 5; pl. 21, fig. 3; text-fig. 6 .

Pseudoemiliania lacunosa (Kamptner) Gartner, 1969. Gulf Coast Assoc. Geol. Soc. Trans., v. 19, p. 598, pl. 2, fig. 9, 10.

Emiliania annula (Cohen) Bukry, 1971. Deep Sea Drilling Proj. Initial Rept., v. 7, p. 1514.

Pseudoemiliania lacunosa (Kamptner), Geitzenauer, 1972. Deep-Sea Res., v. 19, p. 51, fig. 2-1.

Pseudoemiliania lacunosa (Kamptner), Gartner, 1972. Palaeogeog., Palaeoclimatol., Palaeoecol., v. 12, p. 178, pl. 2, fig. 3.

Pseudoemiliania lacunosa (Kamptner), Roth, 1973 (in part). Deep Sea Drilling Proj. Initial Rept., v. 17, p. 731, pl. 3, fig. 4.

Emiliania annula (Cohen), Hekel, 1973, ibid., v. 20, p. 246, pl. 6, fig. 4.

Pseudoemiliania lacunosa (Kamptner), Hay and Beaudry, 1973, ibid., v. 15 , p. 673 , pl. 1 , fig. $17-20$.

Remarks: Because Cohen's (1964) original species was described under the ICZN (International Code of Zoological Nomenclature)-the expressions coccolithophorid fauna and Coccolithophoridae appear on page 235 -it could be validated in genus $\mathrm{Coc}^{-}$ colithites by Loeblich and Tappan (1966) under ICZN Art. 11-g-ii which makes the species name (annula) available even if the genus is invalid. Although a holotype was not designated, the species is, nevertheless, valid by ICZN Art. 73-c which permits typification by a type-series of specimens, syntypes, of equal nomenclatural value. The syntype suite of Cohen (1964) shows the end members of the species as does the form illustrated by Gartner (1969). The specimens of McIntyre et al. (1967), Geitzenauer (1972), and Hekel (1973) are more average forms.

Only a single specimen is shown in cross-polarized light by Cohen, but it is diagnostic for the optical characteristics of the species. These optical characteristics are consistent with the electron micrographs of McIntyre et al. (1967) and Geitzenauer (1972) that show radial, separated, rim elements which give faint images in cross-polarized light. Also prominent is the thick, narrow, central collar cycle of inclined elements that gives a bright cross-polarized light image with inclined extinction lines.

Circular and slightly subcircular forms are included in Emiliania annula. Only the distal rim has slits between elements (Geitzenauer, 1972). This accounts for the peripheral fringe noted by Cohen (1964). The Holocene specimens referred to Cyclolithella anmula (Cohen) by Boudreaux and Hay (1969) in pl. 1, fig. 10 and 17, lack optical and structural characteristics of Cohen's specimens. Similarly, the forms called Cyclolithella annulus (Cohen) by McIntyre and Bé (1967) in pl. 5 , fig. A-D, show rim ultrastructure that is seemingly incompatible with Cohen's cross-polarized light illustration. New species assignments are proposed for these Holocene forms which, although previously ascribed to $C$. annulus, do not possess the optical character of Cohen's type specimens. 


\section{Emiliania ovata Bukry}

Ellipsoplacolithus lacunosus Kamptner, 1963. Ann. Naturh. Mus. Wien, v. 66, p. 172, pl. 9, fig. 50 (invalid).

Pseudoemiliania lacunosa (Kamptner), Ellis, Lohmann, and Wray, 1972. Colo. Sch. Mines Quat., v. 67, no. 3, p. 19, pl. 2, fig. 6.

Emiliania ovata Bukry, 1973. Deep Sea Drilling Proj. Initial Rept., v. 16 , p. 678 , pl. 2 , fig. $10-12$.

Pseudoemiliania lacunosa (Kamptner), Roth, 1973 (in part), ibid., v. 17 , p. 731 , pl. 3 , fig. 6 .

Pseudoemiliania lacunosa (Kamptner), Stradner, 1973 (in part), ibid., v. 13 , p. 1145 , pl. 5 , fig. $1-4$

Emiliania ovata Bukry, Hekel, 1973, ibid., v. 20, p. 246, pl. 6, fig. 1, 3, 5.

Remarks: Specimens of this distinctly elliptical species that have only sparsely slotted distal rims suggest derivation of Emiliania from Crenalithus. Late Pliocene specimens illustrated by Stradner (1973) suggest this relation. Crenalithus, which was probably derived from Reticulofenestra, may have given rise to Gephyrocapsa. In any event, the development of slits in one or both rims is a typical feature of Emiliania. The irregular spacing of slits in species other than E. huxleyi might suggest that the slits are a dissolution feature, however, their common and widespread co-occurrence with unetched species of Crenalithus and Gephyrocapsa indicates a taxonomically distinct skeletal group. Hay (1970) noted that elliptical $E$. ovata had an earlier appearance and later disappearance than circular $E$. annula.

\section{Genus RUCINOLITHUS Stover, 1966}

\section{Rucinolithus? magnus n. sp.}

(Plate 3, Figures 12-14)

Description: Rucinolithus? magnus skeletons are large radial rosettes of six equant crystallites that are rhombic in outline and taper to points. There is only slight imbrication apparent near the center of the rosette. In cross-polarized light, the crystallites are black (optically extinct) when aligned with a polarization direction.

Remarks: Rucinolithus? magnus is distinguished from other species such as Rucinolithus hayi by its larger size, more elongate crystallites, and lesser degree of central imbrication. There is some doubt as to the biologic origin of $R$.? magnus because disaggregated crystallites are the normal mode of occurrence in sediment, intact specimens being the exception. The apparent imbrication and regular symmetry about the center point suggests a biologic origin, but the simple form of the crystallites leaves some doubt.

Occurrence: Rucinolithus? magnus, typically fragmented, is common to abundant in Campanian sediment from Shatsky Rise in Cores 21 to 27 (186 to $252 \mathrm{~m}$ ) at Site 305 . It is most abundant in Cores 23 to 25. Fragments similar to R.? magnus occur in Campanian sediment of the Magellan Rise (lat $7^{\circ} 4.1^{\prime} \mathrm{N}$, long $176^{\circ} 49.5^{\prime} \mathrm{W}$ ) in Cores 50 to 53 (759 to $796 \mathrm{~m})$ at DSDP Site 167.

Size: $10-20 \mu$, maximum diameter; holotype $15 \mu$.

Holotype: USNM 210896 (Plate 3, Figures 12-14).

Type locality: Northwest Pacific Ocean, Sample 305-23-3, 137-138 $\mathrm{cm}(209 \mathrm{~m})$

\section{Genus UMBILICOSPHAERA Lohmann, 1902 \\ Umbilicosphaera hulburtiana Gaarder}

?Cyclolithella annulus (Cohen) McIntyre and Bé, 1967 (in part). DeepSea Res., v. 14 , p. 568 , pl. 5 , fig. C.

Cyclolithella annula (Cohen) Boudreaux and Hay, 1969. Rev. Española Micropaleontol., v. 1, p. 257, pl. 1, fig. 10-17.

Umbilicosphaera hulburtiana Gaarder, 1970. Nytt Mag. Bot., v. 17, p. 121 , fig. $7,8, ? 9$.

Remarks: As illustrated and discussed by Boudreaux and Hay (1969), this species is circular to subcircular, has a distal shield of about 35 trapezoidal elements, a smaller proximal shield, and large central opening. The central tube is thin and shows little character in cross-polarized light.

Although comparable in size and shape to Emiliania annule (Cohen), Umbilicosphaera hulburtiana is distinguished by having flush trapezoidal distal rim elements instead of I-shaped elements and slits. In addition to the different shape of the distal rim elements, the central collar of $U$. hulburtiana is much smaller and less distinctive in crosspolarized light than that of E. annula. Cyclococcolithina? cricota (Gartner) has the same general shape as $U$. hulburtiana, but can be distinguished by its greater number of narrow rim elements and prominent central collar cycle.
Cyclolithella annulus specimens of McIntyre and Bé (1967) appear to include two generic kinds.a The specimen in plate 5 , fig. $C$ may be a distal shield of $U$. hulburtiana. Umbilicosphaer hulburtiana is reported from the late Quaternary of the Gulf of Mexico, Caribbean Sea, and Atlantic Ocean.

\section{Genus WATZNAUERIA Reinhardt, 1964}

$$
\text { Watznaueria frequens (Noël) n. comb. }
$$

Ellipsagelosphaera frequens Noël, 1965. Note préliminaire sur des Coccolithes jurassiques. Cahiers Micropaleontol., no. 1, p. 8, fig. 35$39,42$.

Ellipsagelosphaera frequens Noël, 1965. Sur les Coccolithes du Jurassique Européen et d'Afrique du Nord; Paris, Centre Natl. Recherche Sci., p. 119, fig. 35-40; pl. 11, fig. 7-10; pl. 12, fig. 1-10; pl. 13, fig. 1-10.

Watznaueria communis Reinhardt, Proto Decima, 1974 (in part). Deep Sea Drilling Proj. Initial Rept., v. 27, p. 608, pl. 4, fig. 26 (not fig. 21,22 ).

Remarks: Noël described this species as having variable central tube structure-open, partially barred, or closed-in a manner similar to Quaternary Coccolithus pelagicus. Study of a more analogous, dominantly Late Cretaceous species Watznaueria barnesae also showed variation in closure of the central opening (Bukry, 1969). But no intermediate, barred specimens could be determined as transitions in that species. Although the holotype of $W$. frequens is a barred specimen, the paratype suite and species diagnosis clearly include opentube forms. Such forms are most typical in Early Cretaceous assemblages at Site 306. These specimens are distinguished from $W$. barnesae by smaller size and more open central area; they are distinguished from $W$. ovata by their much smaller central opening. A possible relation between barresd forms of Watznaueria frequens and W. communis has been uggested by Perch-Nielsen (1968)

\section{Watznaueria oblonga Bukry}

Watznaueria oblonga Bukry, 1969. Kansas Univ. Paleontol. Contrib., Protista, v. 2, p. 33, pl. 11, fig. 8-10.

Flabellites biforaminis Thierstein, 1973. Osterreichische Geol. Bundesanst. Abh., v. 29, p. 41, pl. 5, fig. 1-12.

Flabellites biforaminis Thierstein, Proto Decima, 1974. Deep Sea Drilling Proj. Initial Rept., v. 27, p. 614, pl. 3, fig. 31, 32; pl. 7, fig. 9.

Remarks: Watznaueria oblonga has a distinctive oblong central area with a low-profile, X-shaped cross separating two perforations or depressions (compare distal view electron micrographs of Bukry, 1969; Thierstein, 1973). Originally recorded in the Santonian of Texas, it was later recorded with excellent photomicrographs from the Aptian to Cenomanian of France, Switzerland, and the North Atlantic (Thierstein, 1973). At North Pacific sites of Leg 32 it is most common in Aptian and Barremian strata.

\section{Watznaueria ovata Bukry}

not Watznaueria communis Reinhardt, 1964. Deutsche Akad. Wiss. Berlin Monatsber., v. 6, p. 756, pl. 2, fig. 5; text-fig. 6ab. not Ellipsagelosphaera frequens Noël, 1965. Note préliminaire sur des Coccolithes jurassiques. Cahiers Micropaleontol., no. 1, p. 8, fig. $35-39,42$.

not Watznaueria communis Reinhardt, Reinhardt, 1966. Freiberger Forsch., no. C196, p. 17, pl. 4, fig. 3, 5, 6; (?) pl. 23, fig. 5; text-fig.

not Ellipsagelosphaera communis (Reinhardt) Perch-Nielsen, 1968. Biol. Skr. Danske Vidensk. Selsk., v. 16, p. 70, fig. 33cd.

Watznaueria ovata Bukry, 1969. Kansas Univ. Paleontol. Contrib., Protista, art. 2, p. 33, pl. 11, fig. 11, 12.

not Watznaueria communis Reinhardt, Rood, Hay, and Barnard, 1971. Eclog. Geol. Helv., v. 64 , p. 268 , pl. 5, fig. 1-4.

Watznaueria communis Reinhardt, Reinhardt, 1971. Freiberger Forsch., no. C267, p. 34 (not text-fig. 38).

Ellipsagelosphaera ovata (Bukry) Black, 1973. Palaeontogr. Soc. Monogr., v. 127, p. 71, pl. 26, fig. 10-12.

?Watznaueria communis Reinhardt, Thierstein, 1973. Osterreichische Geol. Bundesanst. Abh., v. 29, p. 43, pl. 6, fig. 17.

Watznaueria communis Reinhardt, Proto Decima, 1974 (in part). Deep Sea Drilling Proj. Initial Rept., v. 27, p. 608, pl. 4, fig. 21, 22 (not 26).

Remarks: Watznaueria communis Reinhardt was originally described to have a central opening with a recessed solid plate that arches 
up so as to divide the central area in half with a ridge. Although the photograph of the holotype may show a species with overgrowth on a central-area bar, or an open form filled with debris, the diagram and description are not questionable-the name $W$. communis clearly was assigned to a form with a solid central-area plate or central ridge. This concept was followed by Reinhardt (1964, 1966); Perch-Nielsen (1968); and Rood et al. (1971).

In 1969, because no name was available for specimens of Watznaueria having a large open central pore, the species $W$. ovata was described and illustrated (Bukry, 1969). Later, Reinhardt (1971) placed $W$. ovata in synonymy with $W$. communis and eliminated mention of the central-area structure. Although minor emendation of descriptions may be helpful in clarifying minor points of diagnosis, the central-area structures of the genus Watznaueria are too specifically diagnostic to emend the definition of a form with a solid central plate and ridge structure to a concept with a large open, central pore.

\section{REFERENCES}

Berggren, W.A. and Van Couvering, J., 1973. Late Neogene chronostratigraphy, biostratigraphy, biochronology, and paleoclimatology: Woods Hole Oceanog. Inst. Tech. Rept. 73-40 (unpublished manuscript).

Boudreaux, J.E. and Hay, W.W., 1967. Zonation of the latest Pliocene-Recent interval: Gulf Coast Assoc. Geol. Soc. Trans., v. 17, p. 443-445.

1969. Calcareous nannoplankton and biostratigraphy of the late Pliocene-Pleistocene-Recent sediments in the Submarex cores: Rev. Española Micropaleontol., v. 1, p. 249-292.

Bukry, D., 1969. Upper Cretaceous coccoliths from Texas and Europe: Kansas Univ. Paleont. Contr., Protista, v. 2, 79 p.

1971. Cenozoic calcareous nannofossils from the Pacific Ocean: San Diego Soc. Nat. History Trans., v. 16, p. 303-327.

1973a. Low-latitude coccolith biostratigraphic zonation. In Edgar, N.T., Saunders, J.B., et al. Initial Reports of the Deep Sea Drilling Project, Volume 15: Washington (U.S. Government Printing Office), p. 685-703

, 1973b. Coccolith stratigraphy, eastern equatorial Pacific, Leg 16 Deep Sea Drilling Project. In van Andel, Tj.H., Heath, G.R., et al., Initial Reports of the Deep Sea Drilling Project, Volume 16: Washington (U.S. Government Printing Office), p. 653-711.

1975. Silicoflagellate and coccolith stratigraphy, Deep Sea Drilling Project Leg 29. In Kennett, J.P., Houtz, R.E., et al., Initial Reports of the Deep Sea Drilling Project, Volume 29: Washington (U.S. Government Printing Office), p. 845-872.

in press. Phytoplankton stratigraphy, southwest Pacific, Deep Sea Drilling Project Leg 30: In Andrews, J.E., Packham, G., et al., Initial Reports of the Deep Sea Drilling Project, Volume 30.

Bukry, D. and Bramlette, M.N., 1970, Coccolith age determinations Leg 3, Deep Sea Drilling Project. In Maxwell, A.E., von Herzen, R., et al., Initial Reports of the Deep Sea Drilling Project, Volume 3: Washington (U.S. Government Printing Office), p. 589-611.

Bukry, D. and Foster, J.H., 1973, Silicoflagellate and diatom stratigraphy, Leg 16, Deep Sea Drilling Project. In van Andel, Tj. H., Heath, G.R., et al., Initial Reports of the Deep Sea Drilling Project, Volume 16: Washington (U.S. Government Printing Office), p. 815-871.

Burns, R.E., et al., 1973. Explanatory notes. Initial Reports of the Deep Sea Drilling Project, Volume 21: Washington (U.S. Government Printing Office), p. 5-16.

Cohen, C.L.D., 1964. Coccolithophorids from two Caribbean deep-sea cores: Micropaleontology, v. 10, p. 231-250.
Edwards, A.R., 1971. A calcareous nannoplankton zonation of the New Zealand Paleogene: Plankt. Conf. Proc. 2nd, p. 381-419.

Gartner, S., Jr., 1969. Correlation of Neogene planktonic foraminifer and calcareous nannofossil zones: Gulf Coast Assoc. Geol. Socs. Trans., v. 19, p. 585-599.

1972. Late Pleistocene calcareous nannofossils in the Caribbean and their interoceanic correlation: Palaeogeogr., Palaeoclimatol., Palaeoecol., v. 12, p. 169 191.

1973. Absolute chronology of the late Neogene calcareous nannofossil succession in the equatorial Pacific: Geol. Soc. Am. Bull., v. 84, p. 2021-2034.

1974. Nannofossil biostratigraphy, Leg 22, Deep Sea Drilling Project. In von der Borch, C.C., Sclater, J.G., et al., Initial Reports of the Deep Sea Drilling Project, Volume 22: Washington (U.S. Government Printing Office), p. 577-599.

Geitzenauer, K.R., 1972. The Pleistocene calcareous nannoplankton of the subantarctic Pacific Ocean: Deep-Sea Res., v. 19 , p. $45-60$.

Gemeinhardt, K., 1930. Silicoflagellatae. In Rabenhorst, L. (Ed.), Kryptogamen-Flora von Deutschland: Osterreich und der Schweiz, Akad. Verlagsgesellschaft, v. 10, p. 1-87.

Hay, W.W., 1970. Calcareous nannofossils from cores recovered on Leg 4. In Bader, R.G., Gerard, R.D., et al., Initial Reports of the Deep Sea Drilling Project, Volume 4: Washington (U.S. Government Printing Office), p. 455501 .

Hay, W.W. and Beaudry, F.M., 1973. Calcareous nannofossils-Leg 15, Deep Sea Drilling Project. In Edgar, N.T., Saunders, J.B., et al., Initial Reports of the Deep Sea Drilling Project, Volume 15: Washington (U.S. Government Printing Office), p. 625-683.

Hekel, H., 1973. Nannofossil biostratigraphy, Leg 20, Deep Sea Drilling Project. In Heezan, B.C., MacGregor, I., et al., Initial Reports of the Deep Sea Drilling Project, Volume 20: Washington (U.S. Government Printing Office), p. 221-247.

Kamptner, E., 1963. Coccolithineen-Skelettreste aus Tiefseeablagerungen des Pazifischen Ozeans: Ann. Naturh. Mus. Wien, v. 66, p. 139-204.

Ling, H.Y., 1973. Silicoflagellates and ebridians from Leg 19. In Creager, J.S., Scholl, D.W., et al., Initial Reports of the Deep Sea Drilling Project, Volume 19: Washington (U.S. Government Printing Office), p. 751-797.

Loeblich, A.R., Jr., and Tappan, H., 1966. Annotated index and bibliography of the calcareous nannoplankton: Phycologia, v. 5, p. 81-216.

1970. Annotated index and bibliography of the calcareous nannoplankton V: Phycologia, v. 9, p. 157-174.

Martini, E., 1971. Standard Tertiary and Quaternary calcareous nannoplankton zonation: Plankt. Conf. Proc. 2nd, p. $739-785$.

McIntyre, A. and Bé, A.W.H., 1967. Modern Coccolithophoridae of the Atlantic Ocean-I. Placoliths and cyrtoliths: Deep-Sea Res., v. 14, p. 561-597.

McIntyre, A., Bé, A.W.H., and Preikstas, R., 1967. Coccoliths and the Pliocene-Pleistocene boundary: Progr. Oceanogr., v. 4 , p. $3-25$.

Mohler, H.P., and Hay, W.W., 1967. Zonation of the Paleocene-lower Eocene interval: Gulf Coast Assoc. Geol. Socs. Trans., v. 17, p. 432-437.

Perch-Nielsen, K., 1968. Der Feinbau und die Klassifikation der Coccolithen aus dem Maastrichtien von Dänemark: Biol. Skr. Danske Vidensk. Selsk., v. 16, p. 1-96. 1972. Remarks on Late Cretaceous to Pleistocene coccoliths from the North Atlantic. In Berggren, W.A., 
Laughton, A.S., et al., Deep Sea Drilling Project, Volume 12: Washington (U.S. Government Printing Office), p. 1003-1069.

Reinhardt, P., 1964. Einige Kalkflagellaten-Gattungen (Coccolithophoriden, Coccolithineen) aus dem Mesozoikum Deutschlands: Deutsch. Akad. Wiss. Berlin Monatsber., v. 6, p. $749-759$.

1966. Zur Taxionomie und Biostratigraphie des fossilen Nannoplanktons aus dem Malm, der Kreide und dem Alttertiär Mittleuropas: Freiberger Forschungshefte, no. C196, p. 5-109.

1971. Synopsis der Gattungen und Arten der mesozoischen Coccolithen und anderer kalkiger Nannofossilien, Teil III: Freiberger Forschungshefte, no. C267, p. 19-41.

Rood, A.P., Hay, W.W., and Barnard, T., 1971. Electron microscope studies of Oxford Clay coccoliths: Eclog. Geol. Helv., v. 64 , p. $245-272$.

Roth, P.H., 1973. Calcareous nannofossils-Leg 17, Deep Sea Drilling Project. In Winterer, E.L., Ewing, J.I., et al., Initial Reports of the Deep Sea Drilling Project, Volume 17: Washington (U.S. Government Printing Office), p. 695-795.
Roth, P.H. and Thierstein, H., 1972. Calcareous nannoplankton: Leg 14 of the Deep Sea Drilling Project. In Hayes, D.E., Pimm, A.C., et al., Initial Reports of the Deep Sea Drilling Project, Volume 14: Washington (U.S. Government Printing Office), p. 421-485.

Stadum, C.J. and Burckle, L.H., 1973. A silicoflagellate ooze from the east Falkland Plateau: Micropaleontology, v. 19, p. 104-109.

Stradner, H., 1973, Catalogue of calcareous nannoplankton from sediments of Neogene age in the eastern North Atlantic and the Mediterranean Sea. In Ryan, W.B.F., Hsü, K.J., et al., Initial Reports of the Deep Sea Drilling Project, Volume 13: Washington (U.S. Government Printing Office), p. 1137-1199.

Theyer, F. and Hammond, S. R., 1974. Paleomagnetic polarity sequence and radiolarian zones, Brunhes to polarity epoch 20: Earth Planet. Sci. Lett., v. 22, p. 307-319.

Thierstein, H.R., 1973. Lower Cretaceous calcareous nannoplankton biostratigraphy: Osterreichische Geol. Bundesanst. Abh., v. 29, p. 1-52. , in press. Calcareous nannoplankton biostratigraphy at the Jurassic-Cretaceous boundary: Mem. of Bur. Réch. Geol. Min. Mem. 



\section{PLATE 1}

Silicoflagellates from DSDP Legs 32 and 19 Magnification $800 \times$; scale bar equals $10 \mu \mathrm{m}$.

Figures 1-5 Dictyocha aspera clinata n. subsp.

1. USNM 210879, Sample 303-3-1, 140-142 cm $(117 \mathrm{~m})$.

2. Holotype, USNM 210878, Sample 303-3-5, 30$32 \mathrm{~cm}(123 \mathrm{~m})$.

3. USNM 210880, Sample 192-19-1, 70-71 cm (392 m).

4. USNM 210881, Sample 303-3-1, 140-142 cm $(117 \mathrm{~m})$.

5. USNM 210882, Sample 303-3-1, 140-142 cm $(117 \mathrm{~m})$.

Figures 6,7 Distephanus boliviensis jimlingii $\mathrm{n}$. subsp.

6. Holotype, USNM 210883, Sample 303-2-5, 90$92 \mathrm{~cm}(69 \mathrm{~m})$.

7. USNM 210884, Sample 192-13-2, 69-70 cm $(233 \mathrm{~m})$. 
PLATE 1
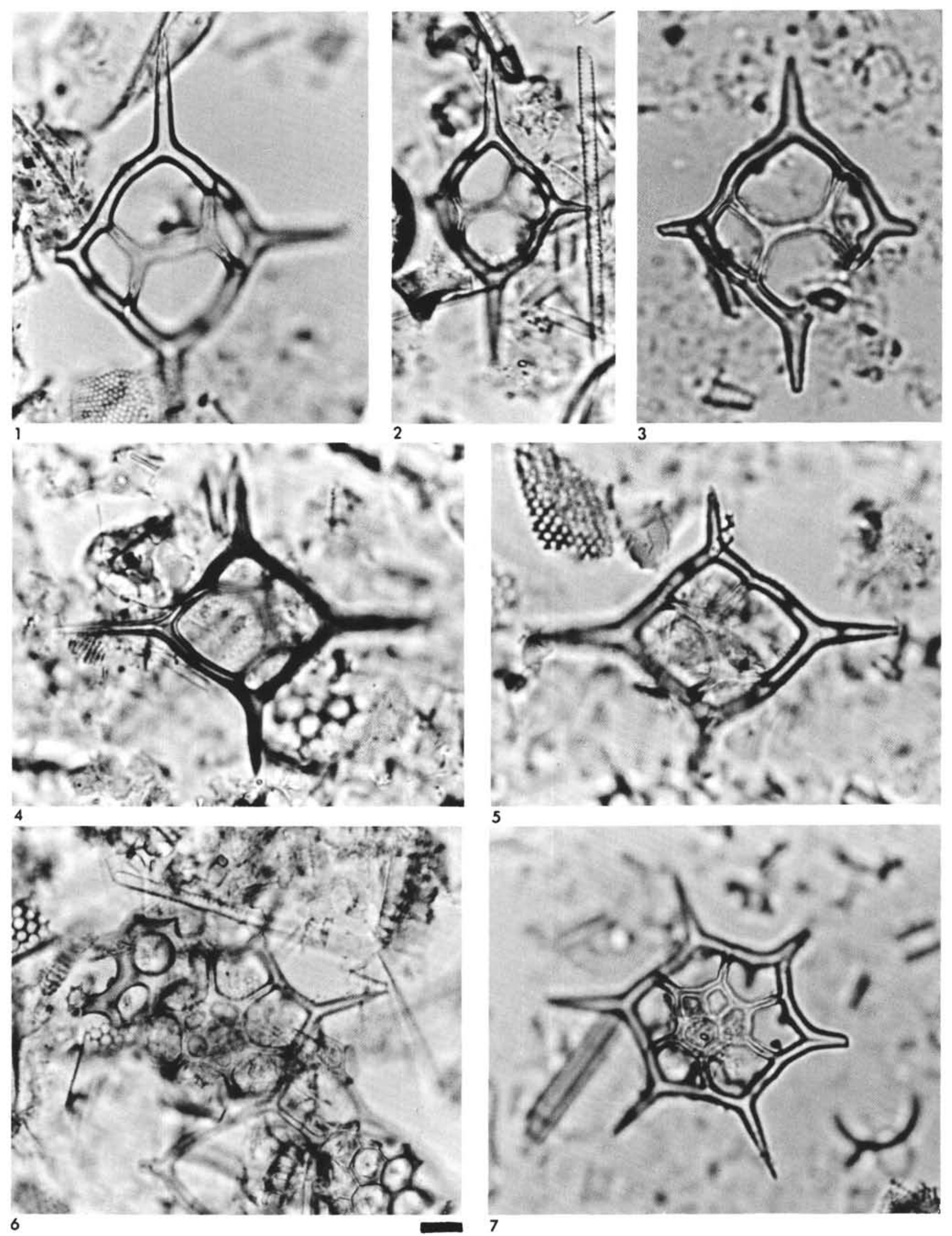


\section{PLATE 2}

Silicoflagellates from DSDP Legs 32,19 , and 18

Magnification $800 \times$; scale bar equals $10 \mu \mathrm{m}$.

Figure 1 Distephanus boliviensis jimlingii n. subsp. USNM 210885, Sample 192-13-2, 69-70 cm (233 m).

Figures 2-7 Distephanus boliviensis frugalis $\mathrm{n}$. subsp. 2, 3. USNM 210887, Sample 173-14-3, $20-21 \mathrm{~cm}$ (123 m); double skeleton.

4, 5. USNM 210888, Sample 173-14-3, $20-21 \mathrm{~cm}$ $(123 \mathrm{~m})$.

6. Holotype, USNM 210886, Sample 304-1-2, 63$65 \mathrm{~cm}(108 \mathrm{~m})$.

7. USNM 210889, Sample 304-1-2, 63-65 cm (108 $\mathrm{m})$.

Figures 8,9 Distephanus speculum elongatus n. subsp. Holotype, USNM 210890, Sample 303-2-1, 86-88 cm $(63 \mathrm{~m})$. 
PLATE 2
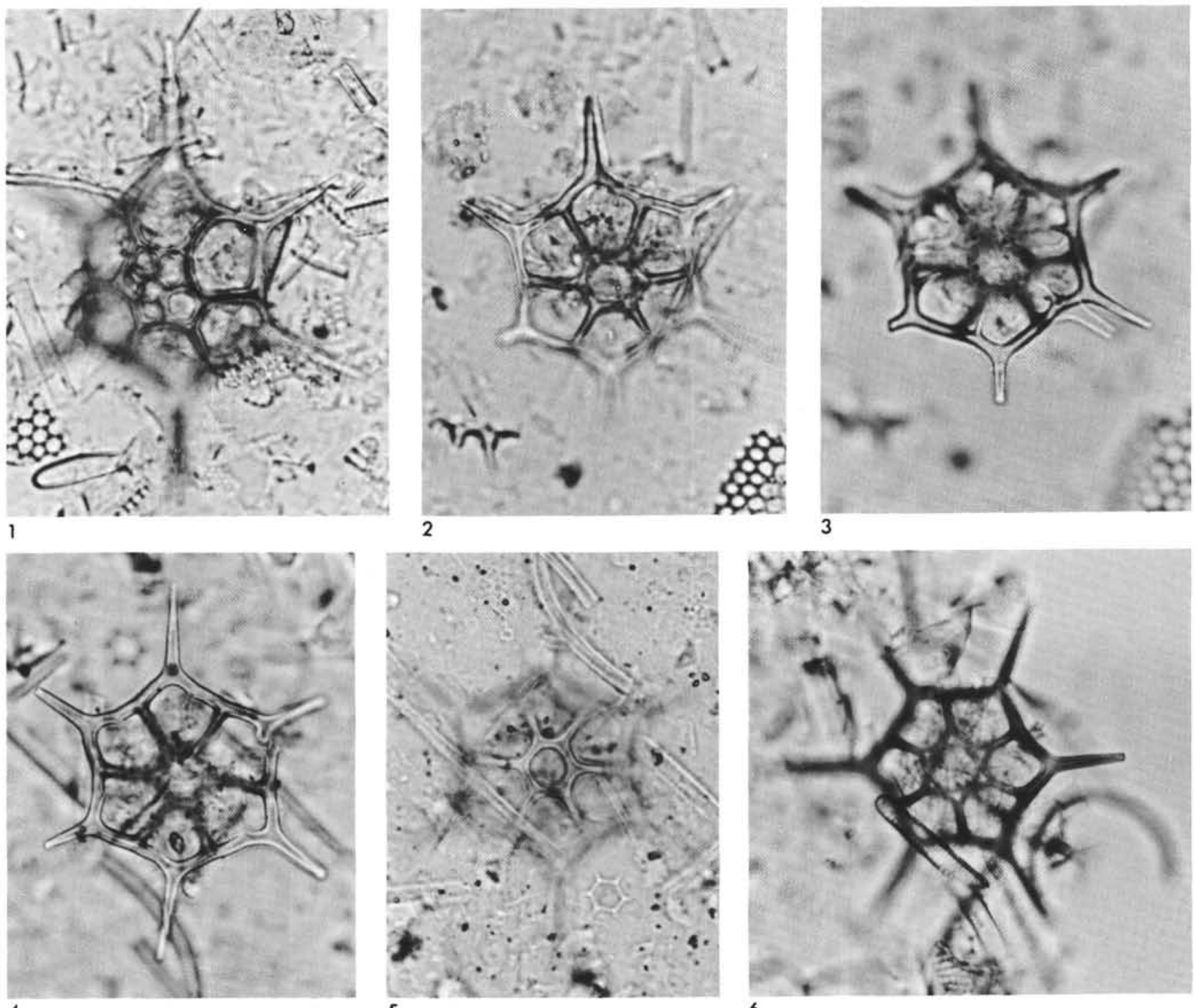

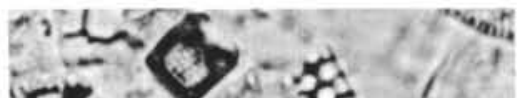

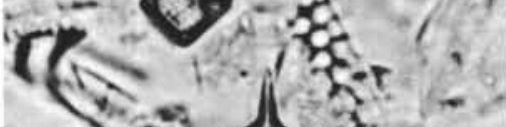

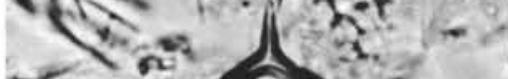

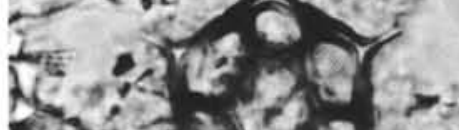

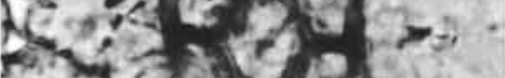
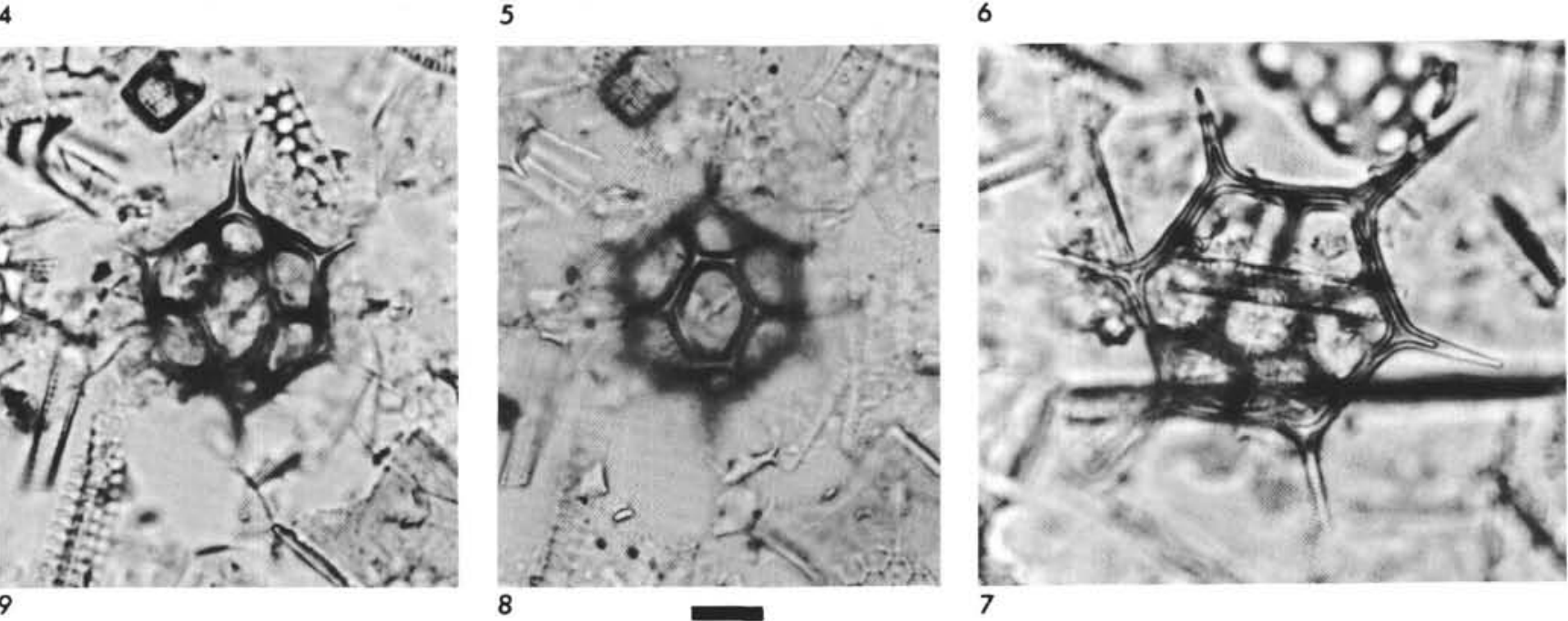


\section{PLATE 3}

Silicoflagellates and coccoliths from DSDP Legs 32 and 29 Figures 1-3 Magnification $800 \times$; scale bar equals $10 \mu \mathrm{m}$. Figures 4, 5, 8-14 Magnification 2000X; scale bar equals $5 \mu \mathrm{m}$. Figures 6, 7 Magnification 2600×; scale bar equals $5 \mu \mathrm{m}$.

Figures 1-3 Distephanus speculum elongatus n. subsp.

1, 2. USNM 210891, Sample 278-8-2, $75-76 \mathrm{~cm}$ $(160 \mathrm{~m})$.

3. USNM 210892, Sample 278-8-2, 75-76 cm (160 $\mathrm{m})$.

Figures 4-11 Cylindralithus? echinus n. sp. Sample 305-18-3, $120-121 \mathrm{~cm}(161 \mathrm{~m})$.

4, 5. Holotype, USNM 210893, side view. (5) cross-polarized light.

6 , 7. USNM 210894, side view. (7) cross-polarized light.

8-11. USNM 210895 , top view. $(8,9)$ high focus $(10,11)$ low focus $(9,11)$ cross-polarized light.

Figures 12-14 Rucinolithus? magnus n. sp. Holotype, USNM 210896, Sample 305-23-3, 137-138 cm (209 m). $(13,14)$ cross-polarized light, (13) one set of elements (dark) aligned to polarization direction, (14) same set of elements (faint) rotated $17^{\circ}$ from polarization direction. 
PLATE 3

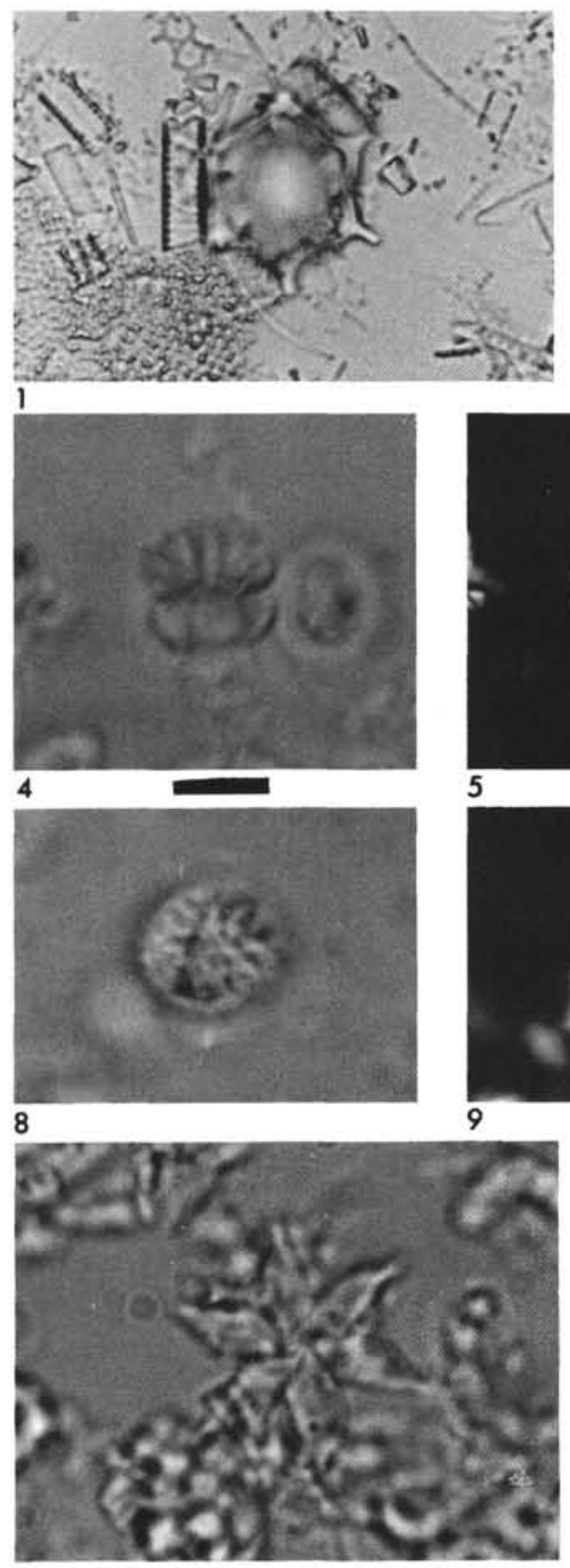

12
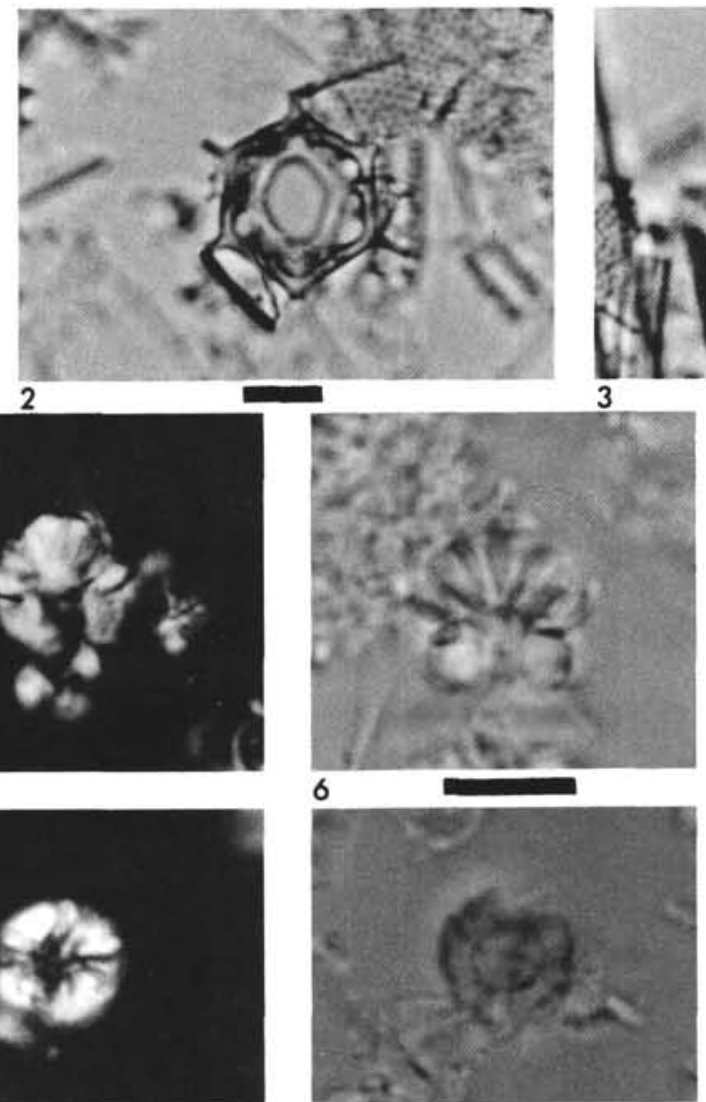

10

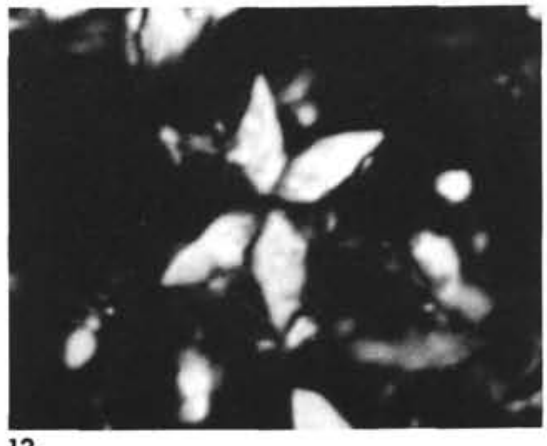

13
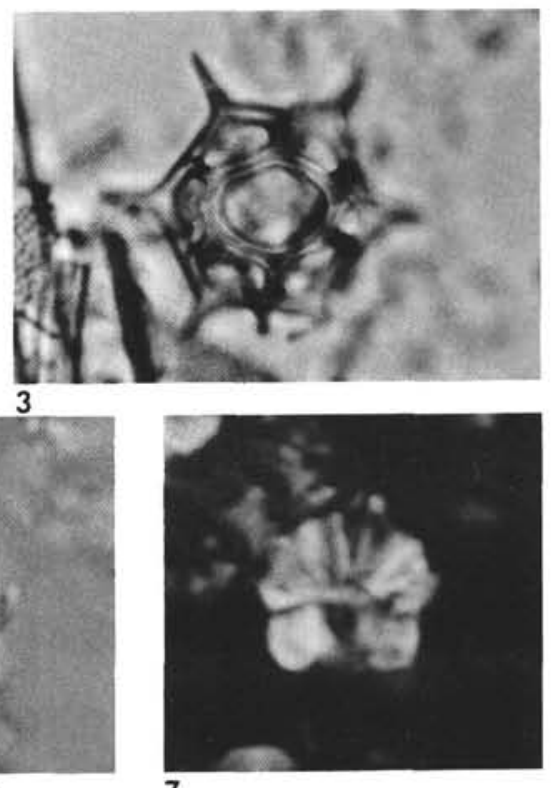

7

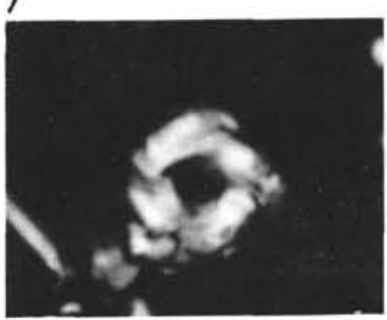

11

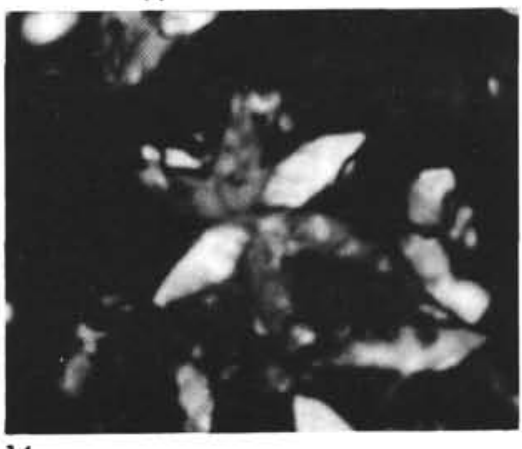

14 
PLATE 4

Silicoflagellates from DSDP Legs 32 and 30 .

Figures 1-7 Magnification $800 \times$; scale bar equals $10 \mu \mathrm{m}$.

Figure 8 Magnification $600 \times$; scale bar equals $10 \mu \mathrm{m}$.

Figures 1-3 Dictyocha pulchella $\mathrm{n}$. sp.

1. Holotype, USNM 213297, Sample 285-5-6, 50-

$51 \mathrm{~cm}(82 \mathrm{~m})$.

2. USNM 213298, Sample $285-4-6,50-51 \mathrm{~cm}(62$ $\mathrm{m})$.

3. USNM 213299, Sample 303-4-2, $28-29 \mathrm{~cm}$ (175 $\mathrm{m})$.

Figures 4, 8 Dictyocha fibula perlaevis (Frenguelli)

4. Sample 304-1, CC (112 m).

8. Specimen at left, Sample 304-1-1, 130-132 cm $(107 \mathrm{~m})$.

Figures 5, 6 Dictyocha rhombica (Schulz)

5 , 6. Sample $285-4-6,50-51 \mathrm{~cm}(62 \mathrm{~m})$.

Figures 7, 8 Dictyocha aspera aspera (Lemmermann)

7. Sample 304-1, CC (112 m).

8. Specimen at right, Sample $304-1-1,130-132 \mathrm{~cm}$ $(107 \mathrm{~m})$. 
PLATE 4
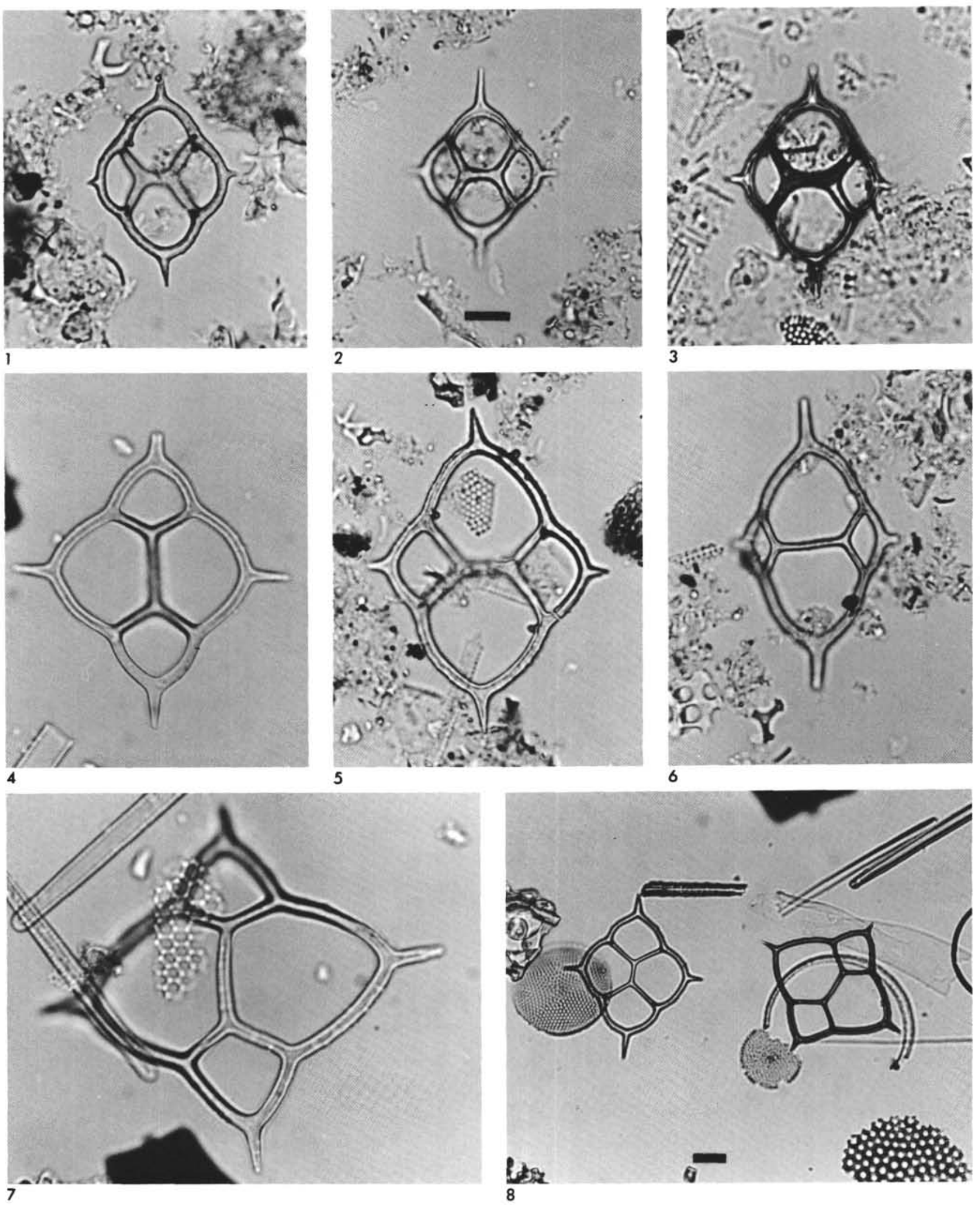